Article

\title{
Synthesis of Polyoxygenated Heterocycles by Diastereoselective Functionalization of a Bio-Based Chiral Aldehyde Exploiting the Passerini Reaction
}

\author{
Gabriella Vitali Forconesi ${ }^{1}$, Luca Banfi ${ }^{1}{ }^{1}$, Andrea Basso ${ }^{1}{ }^{10}$, Chiara Lambruschini ${ }^{1}$, \\ Lisa Moni ${ }^{1}$ (D) and Renata Riva ${ }^{2, *}$ \\ 1 Dipartimento di Chimica e Chimica Industriale, Università di Genova, via Dodecaneso 31, \\ 16146 Genova, Italy; gabriella.vitali.f@gmail.com (G.V.F.); banfi@chimica.unige.it (L.B.); \\ andrea.basso@unige.it (A.B.); chiara.lambruschini@unige.it (C.L.); lisa.moni@unige.it (L.M.) \\ Dipartimento di Farmacia, Università di Genova, viale Cembrano 4, 16147 Genova, Italy \\ * Correspondence: renata.riva@unige.it; Tel.: +39-010-3536106
}

Academic Editor: Philippe Compain

Received: 22 June 2020; Accepted: 9 July 2020; Published: 15 July 2020

\begin{abstract}
A chiral bio-based building block, prepared by the lipase-mediated desymmetrization of an erythritol derivative, was further functionalized and then submitted to stereoselective Passerini reactions, allowing the synthesis of a small library of new molecules. Thanks to the presence of different functional groups, further cyclizations were performed providing bicyclic polyoxygenated heterocycles.
\end{abstract}

Keywords: multicomponent reactions; Passerini reaction; diastereoselective reactions; lipase; desymmetrization; Michael reaction; bio-based; biomass

\section{Introduction}

Over the last 50 years, a tremendous progress in methodologies and techniques of organic synthesis has made possible the preparation of nearly any molecule. However, not all the total syntheses reported over the years can be scaled up into cost-effective and environmentally sustainable industrial processes. According to the principles of Green Chemistry, issues such as step economy, atom economy, and operational simplicity are becoming more and more important.

Consequently, also the synthesis of libraries of compounds profits from the development of new environmentally benign, short, selective, and atom and step economic synthetic pathways.

However, the sustainability of a synthesis not only relies on the employed methodology, and the availability of the starting materials plays a very important role as well. In the last few decades, building blocks extracted from oil or other fossil materials have been the starting point for many syntheses, including polymerizations. In order to preserve these resources, in recent years, great attention within the scientific community and the governments as well has been given to the alternative exploitation of renewable sources or waste [1]. The most readily accessible biomass is undoubtedly lignocellulosic feedstock, which is a powerful precursor of many bio-based chemicals and polymers [2]. This very complex matrix is characterized by three main components: lignin, cellulose, and hemicelluloses. They can be separated and submitted to degradation processes, allowing the isolation of high added-value molecules, which can be further elaborated by synthetic methodologies or by fermentation processes.

In this context, multicomponent reactions (MCRs) can improve sustainability in both targetand diversity-oriented syntheses [3]. MCRs are still underexploited because of some limitations that hamper their full utilization. For example, they usually rely mostly on commercially available inputs. 
A possible solution is offered by the development of efficient pre-MCR sequences, converting simple bio-based building blocks into more complex (chiral) components. Chiral inputs may be very useful, making it possible the control of diastereoselection during the MCR and in the post-condensation transformations as well, although this goal is not easily achieved [4].

In recent years we synthesized enantiopure chiral building blocks by a chemoenzymatic [5-10] and/or organocatalytic $[7,11,12]$ approach, often using bio-based starting materials $[5,6,9,10]$, and used them for controlling the diastereoselectivity in different isocyanide-based MCRs (Ugi-Joullié [5,7], Passerini [6,8-10], or Ugi [11,12] reactions).

A bio-based building block readily available from lignocellulosic biomass is erythritol 1, which is produced from glycerol [13] or from waste cooking oil [14] by means of osmophilic yeasts, such as Yarrowia lipolytica. This molecule is used as artificial sweetener [15], but it has found many applications in polymer chemistry, such as biodegradable polyurethanes [16,17] or polyesters [18], or in the synthesis of plant derived phthalates [19]. Erythritol, a meso compound, can be efficiently desymmetrized by means of Amano PS lipase [5] to give chiral monoesters, such as $\mathbf{2}$. An appropriate functional group manipulation allowed us to obtain different chiral building blocks, namely pyrroline 3 and aldehyde 4 which were used in diastereoselective Ugi-Joullié [5,9] or a Passerini reaction [9], affording 5 and 6 respectively (Scheme 1).

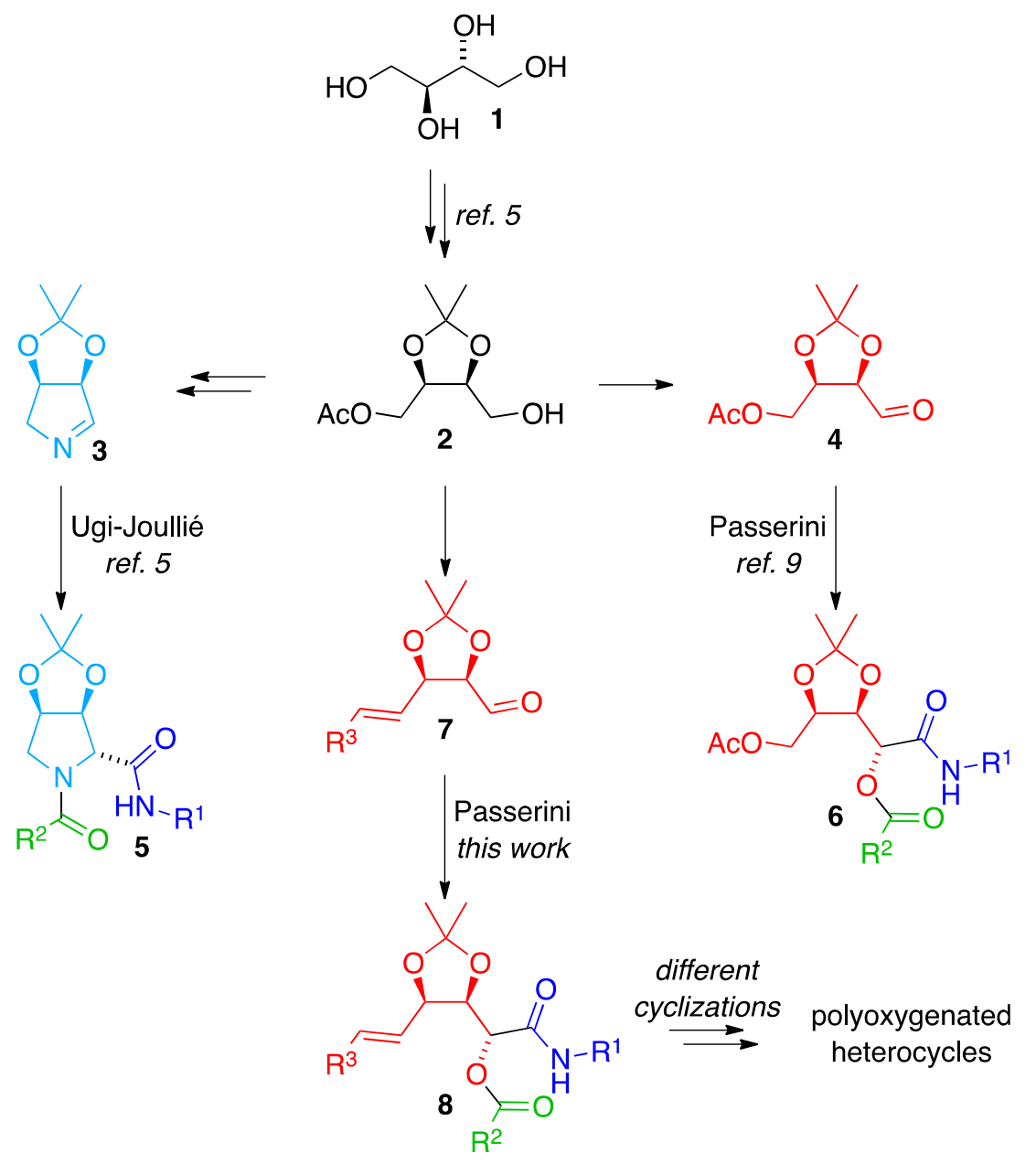

Scheme 1. General strategy for the stereoselective functionalization of the bio-based building block $\mathbf{1}$.

Herein, we present a different elaboration of $\mathbf{2}$, aiming to introduce a double bond. We planned to submit the resulting aldehyde 7 to a diastereoselective Passerini reaction affording 8 , followed by a series of new post-condensation transformations [20] ending up with the synthesis of polyoxygenated heterocycles. 


\section{Results and Discussion}

\subsection{Synthesis of the Bio-Based Precursor of Chiral Aldehyde to Be Used in the Passerini Reaction}

Chiral building block 2 (Scheme 1) can be prepared by the chemoenzymatic desymmetrization of diol 11, which, in turn, was prepared from erythritol 1, as previously described (Scheme 2) $[5,21]$. However, we also developed an efficient alternative synthesis starting from D-isoascorbic acid 9, an antioxidant readily accessible from simple sugars. Actually, lactone 10, prepared through a known procedure [22], can be efficiently reduced with $\mathrm{LiAlH}_{4}$, affording $\mathbf{1 1}$ in high overall yield and avoiding the difficult chromatographic purification that was needed in our previous synthesis. Even if the chirality of $\mathbf{9}$ is destroyed during the transformation into meso-11 and reintroduced during the following lipase-mediated desymmetrization, this is compensated by the high overall yield and by the possibility to obtain both enantiomeric series, thanks to the complementary enzymatic acylation and hydrolysis [5]. Moreover, direct conversion of lactone $\mathbf{1 0}$ into aldehyde $\mathbf{4}$ is not feasible. The starting building block 9 is cheap and renewable.

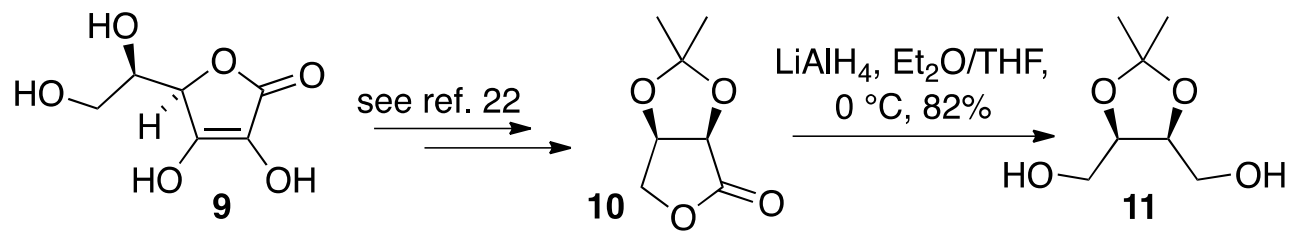

Scheme 2. Alternative synthesis of $\mathbf{1 1 .}$

Initially we planned to synthesize aldehyde 7 (Scheme 1) bearing a terminal double bond $\left(\mathrm{R}^{3}=\mathrm{H}\right)$ [23] and for this purpose we submitted 2 to Swern oxidation followed by Wittig olefination, but, under a variety of conditions, we never succeeded to get $\mathbf{1 2}$ (Scheme 3).

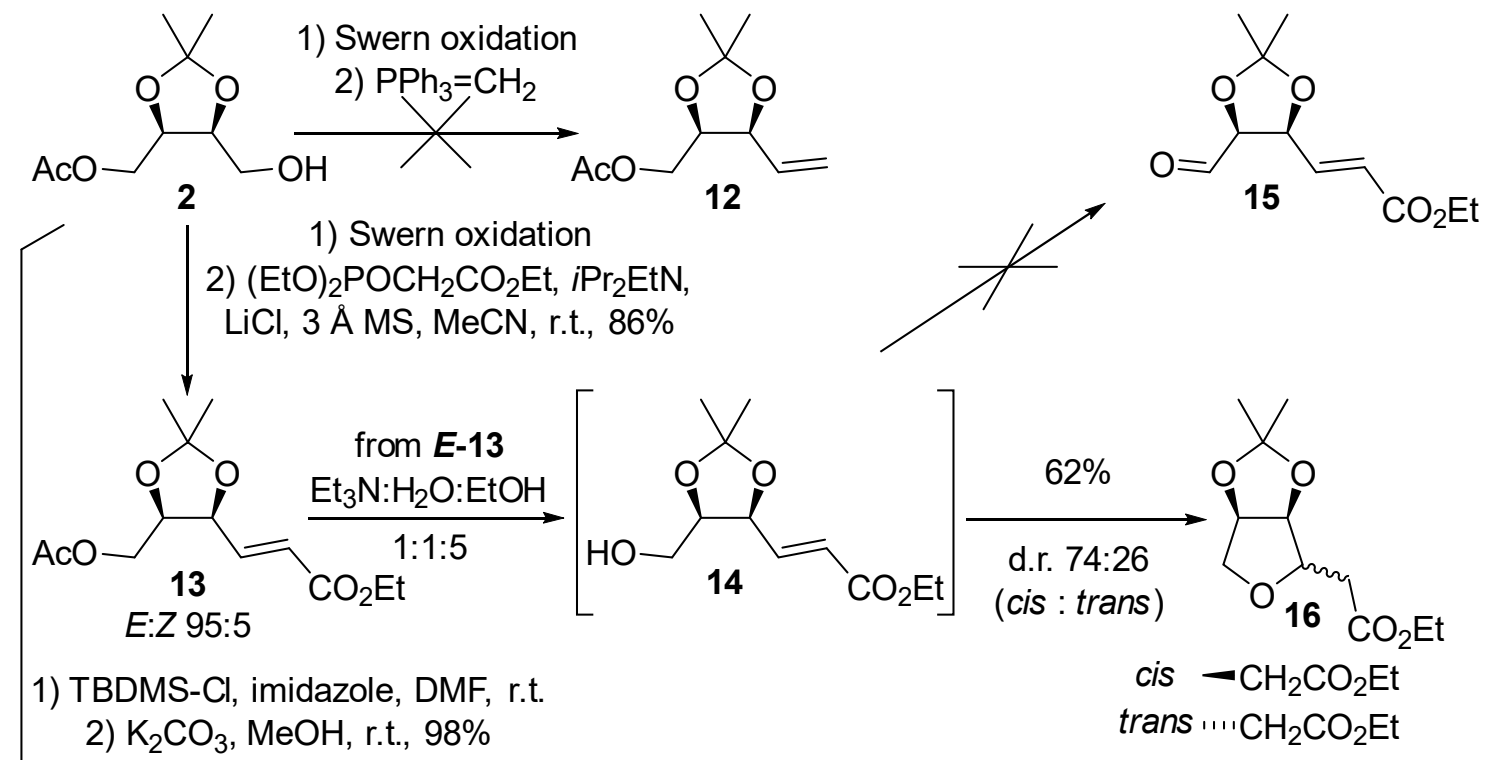

1) Swern oxidation

2) a. $(\mathrm{EtO})_{2} \mathrm{POCH}_{2} \mathrm{CO}_{2} \mathrm{Et}, \mathrm{NaH}$;

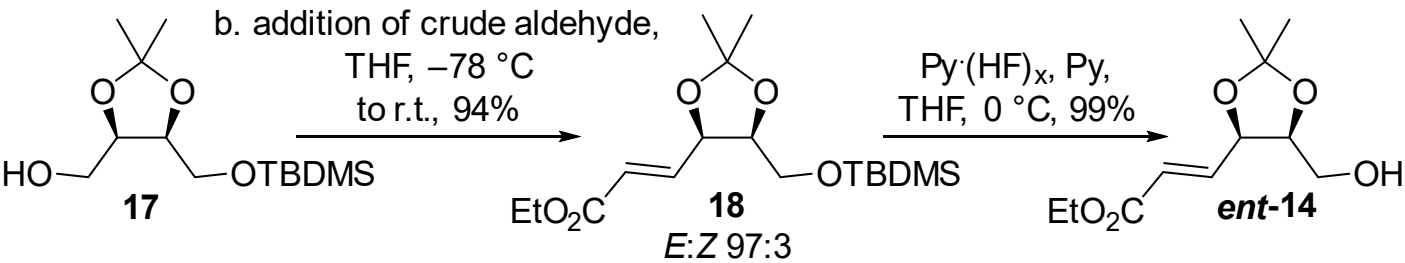

Scheme 3. Synthesis of both enantiomers of 14 . 
Then we switched to the carbethoxymethylenation which has the advantage of introducing two functional groups at once (a double bond conjugated with an ester), which could have enabled exploring different post-condensation transformations after the multicomponent reaction.

However, this reaction turned out to be not so trivial as expected. A Wittig olefination was first performed with (carbethoxymethylene)triphenylphosporane on aldehyde 4: when the aldehyde was prepared by Swern oxidation of 2, compound 13 was isolated in a good (73\%) overall yield, but in a 41:59 $E: Z$ ratio. Also, a partial epimerization (2\%) at the stereogenic center $\alpha$ to the aldehyde was detected, as demonstrated by GC-MS. Switching to TEMPO/(diacetoxyiodo)benzene oxidation and performing the olefination in the presence of triethylamine, the yield increased to $89 \%$ and the diastereomeric ratio reverted to 70:30 (E:Z), but again a partial epimerization $(6 \%)$ occurred.

Thus, we turned to Horner-Wadsworth-Emmons olefination. After careful optimization, the reaction in the presence of lithium chloride and Hünig's base [24] afforded 13 in good overall yield $(86 \%)$ and high stereoselectivity $(95: 5 \mathrm{E}: \mathrm{Z})$, without any trace of epimerization. The minor $\mathrm{Z}$ isomer was readily removed by chromatography.

Then we planned to selectively hydrolyze the acetyl ester moiety on $E-13$ to release 14 , the precursor of aldehyde 15. Initially we tried basic conditions (1 M KOH in $\mathrm{MeOH}, \mathrm{Et}_{3} \mathrm{~N} / \mathrm{H}_{2} \mathrm{O} / \mathrm{MeOH}$ 1:1:5). In all cases, even employing a mild base like $\mathrm{Et}_{3} \mathrm{~N}$, which was successfully used for an analogous of 13 [9], we never identified expected 14, isolating instead the Michael product 16 in good yield $[79 \%(\mathrm{KOH})$ or $88 \%\left(\mathrm{Et}_{3} \mathrm{~N}\right)$ ]. Moreover, we observed a total or a partial transesterification to give the methyl ester analogue of 16. With $\mathrm{KOH}$ transesterification was complete, whereas with $\mathrm{Et}_{3} \mathrm{~N}$ we obtained a Me/Et ratio of 66:34. The substitution of $\mathrm{MeOH}$ with $\mathrm{EtOH}\left(\mathrm{Et}_{3} \mathrm{~N} / \mathrm{H}_{2} \mathrm{O} / \mathrm{EtOH}\right.$ 1:1:5) prevented transesterification but afforded a slower and complete conversion into 16 in a moderate, unoptimized, $62 \%$ overall yield. 16 was obtained as an inseparable diastereomeric mixture (d.r. 74:26, cis:trans, determined by GC-MS).

To avoid basic conditions, we switched to the enzymatic hydrolysis of the acetate. We tried several enzymes, working at $\mathrm{pH} 7$ (phosphate buffer) in the presence of different cosolvents (about $15 \%$ of THF or $\left.i \mathrm{Pr}_{2} \mathrm{O}\right)$ [25] and at different concentrations $(0.07-0.15 \mathrm{M})$. The hydrolysis turned out to be very slow and, only using lipase from Candida antarctica (Novozym 435) we isolated, after 7-8 days, just a moderate amount (around 50\%, depending on the concentration of 13) of 14. Lipase from porcine pancreas, either the commercial one or the one supported on Celite following our protocol [26], was ineffective. On the contrary, lipase from Pseudomonas cepacia from Amano promoted a slow hydrolysis of the acetyl but, after 6 days, only the Michael product 16 was isolated in 54\% yield.

In order to suppress the Michael cyclization, we decided to substitute the acetyl with a protecting group that could be cleaved under acidic conditions, such as the $t$-butyldimethylsilyl ether. It was easily introduced through a high-yield, epimerization-free protection-deprotection sequence affording 17 [23]. Of course, this sequence produces ent-14. However, starting from the pseudoenantiomeric monobutyrate of $\mathbf{2}$, obtained by enzymatic monohydrolysis of the corresponding dibutyrate [5], 14 could be synthesized as well. In this case, the olefination gave best results simply treating the aldehyde with the anion of triethyl phosphonoacetate, affording $E-18$ in almost diastereomerically pure form [23].

Silyl ether removal was not as simple as expected. Under basic conditions, using $n \mathrm{Bu}_{4} \mathrm{NF}$, TBDMS removal was rapidly followed by the intramolecular Michael reaction to give ent-16. Employing $40 \% \mathrm{HF}$ in $\mathrm{MeCN}$ we also observed, as side reaction, the hydrolysis of the acetonide, although this problem was never observed on very similar substrates [5]. 25\% $\mathrm{H}_{2} \mathrm{SiF}_{6}$ in MeCN afforded ent-14 in only $30 \%$ yield, again for the partial cleavage of the acetonide [27].

Finally, we tried hydrogen fluoride pyridine complex (Olah's reagent) in pyridine/THF [28]. After a careful optimization of the reaction conditions, with the aim of reducing the amount of Olah's reagent, we found that lowering from 125 to 35 the equivalents, ent-14 can be isolated in almost quantitative yield, even if a longer time is required ( 3 days vs $30 \mathrm{~h}$ ). 


\subsection{Stereoselective Passerini Reaction}

Ent-14 is the precursor of the chiral aldehyde ent-15 that we wanted to use in the diastereoselective Passerini reaction (Scheme 4). Initially, we decided to oxidize the alcohol with TEMPO/(diacetoxyiodo)benzene in methylene chloride, followed by $t$-butyl isocyanide addition, in a one-pot procedure. The third component, the carboxylic acid (AcOH), is already present, being a by-product of the oxidation. The classic Passerini conditions (entry 1, Table 1) afforded an acceptable overall yield, but only a fair diastereoselectivity (61:39) with anti-20a prevailing.
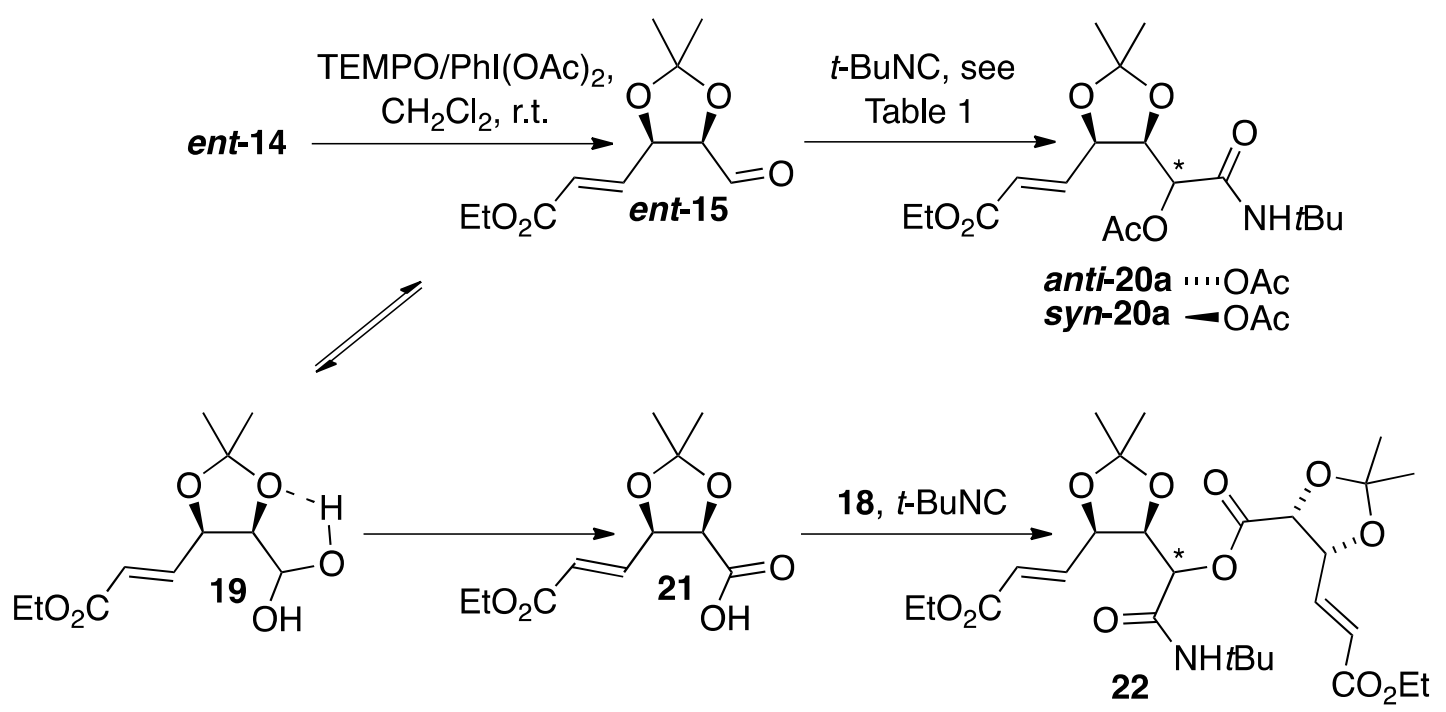

Scheme 4. General strategy for the synthesis of Passerini products 20. In compounds 20 and 22 * means the formation of a mixture of diastereoisomers (both $R$ and $S$ configuration).

Table 1. Preliminary experiments using ent-15, obtained by TEMPO/PhI(OAc) $)_{2}$ oxidation of ent-14.

\begin{tabular}{cccccc}
\hline Entry $^{\mathbf{1}}$ & Solvent & Additive (equiv.) & Temperature $\left({ }^{\circ} \mathbf{C}\right)$ & Yield (\%) & anti-20a:syn-20a $^{2}$ \\
\hline $1^{3}$ & $\mathrm{CH}_{2} \mathrm{Cl}_{2}$ & none & r.t. & 67 & $61: 39$ \\
$2^{3}$ & $\mathrm{CH}_{2} \mathrm{Cl}_{2} / \mathrm{THF}$ & $\mathrm{ZnBr}_{2}(0.4)$ & r.t. & 51 & $76: 24$ \\
$3^{4}$ & $\mathrm{CH}_{2} \mathrm{Cl}_{2} / \mathrm{THF}$ & $\mathrm{ZnBr}_{2}(0.4)$ & r.t. & 55 & $71: 29$ \\
\hline
\end{tabular}

Notes: ${ }^{1} 1.1$ equivalents of isocyanide. ${ }^{2}$ Determined by ${ }^{1} \mathrm{H}-\mathrm{NMR}$; the relative configuration of compounds 20a was determined as reported in the Supplementary Materials; ${ }^{3}$ no drying procedure of the aldehyde. ${ }^{4}$ In the presence of $3 \AA \mathrm{MS}$

In order to increase the d.r., we added $\mathrm{ZnBr}_{2}$, a Lewis acid that proved to be very efficient in Passerini reactions of similar erythritol-derived aldehydes [9]. Moreover, according to our optimized procedure, we diluted the $\mathrm{CH}_{2} \mathrm{Cl}_{2}$ solution of the oxidation step with THF to improve the solubility of the Lewis acid (entry 2). We observed an increased stereoselectivity, but the overall yield was still unsatisfactory. The main problem seems to be the overoxidation of the intermediate aldehyde to carboxylic acid 21, which of course can compete with acetic acid in the multicomponent reaction, affording 22. This overoxidation is likely due to the easy formation, in the presence of humidity, of the hydrated form 19, stabilized by an intramolecular H-bond.

Working under strictly anhydrous conditions ( $3 \AA \mathrm{MS}$ ), we suppressed the overoxidation and the yield increased to some extent but diastereoselectivity slightly decreased (entry 3).

For these reasons, we decided to perform the oxidation under Swern conditions (Scheme 5), which are known to completely suppress overoxidation. Although this protocol does not permit a one-pot procedure, it has the advantage to allow the use of different carboxylic acids in the Passerini reaction. Taking care of the work-up conditions, performed under slightly acidic conditions, we were able to completely avoid the epimerization of aldehyde ent-15, which was used as such, avoiding chromatography, because of its instability over silica gel. When ent-15 was submitted to a 
traditional Passerini reaction in methylene chloride, we isolated a mixture of anti- and syn-20a in excellent $92 \%$ overall yield from ent-14 but with a poor diastereomeric ratio (59:41) (entry 1, Table 2). The use of THF further increased the yield, but not the diastereoselectivity, which was even worse (entry 2).
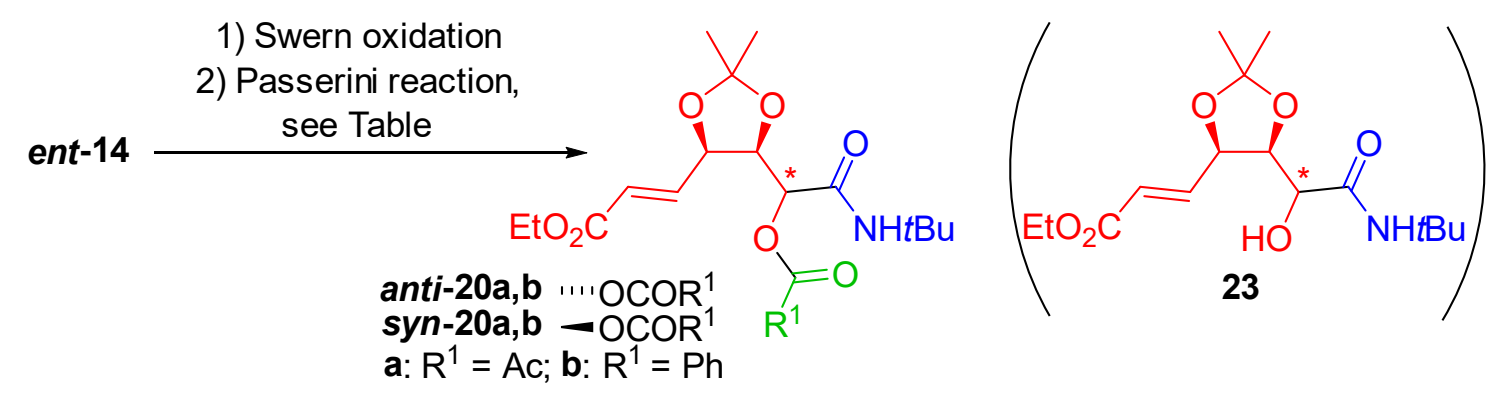

Scheme 5. The stereoselective Passerini reaction described in Table 2. ${ }^{*}$ means the formation of a mixture of diastereoisomers (both $R$ and $S$ configuration).

Table 2. Optimization of the stereoselective Passerini reaction.

\begin{tabular}{|c|c|c|c|c|c|c|c|c|}
\hline Entry $^{1}$ & Product & $\mathbf{R}^{1}$ & Solvent & Additive (equiv.) & Temperature $\left({ }^{\circ} \mathrm{C}\right)$ & Time & Yield (\%) ${ }^{2}$ & anti-20:syn-20 3 \\
\hline 1 & $20 a$ & $\mathrm{Me}$ & $\mathrm{CH}_{2} \mathrm{Cl}_{2}$ & none & 20 & $1.5 \mathrm{~h}$ & 92 & $59: 41$ \\
\hline 2 & $20 a$ & $\mathrm{Me}$ & THF & none & 20 & $42 \mathrm{~h}$ & 97 & $51: 49^{4}$ \\
\hline 3 & $20 a$ & $\mathrm{Me}$ & THF & $\mathrm{ZnBr}_{2}(0.4)$ & 20 & $4 \mathrm{~h}$ & 78 & $80: 20$ \\
\hline 4 & $20 a$ & $\mathrm{Me}$ & THF & $\mathrm{Zn}(\mathrm{OAc})_{2}(1.1)^{5}$ & 20 & $19 \mathrm{~h}$ & 79 & $56: 44$ \\
\hline 5 & $20 b$ & $\mathrm{Ph}$ & THF & none & 20 & $23 \mathrm{~h}$ & 97 & $45: 55$ \\
\hline 6 & $20 b$ & $\mathrm{Ph}$ & THF & $\mathrm{ZnBr}_{2}(0.4)$ & 20 & $17 \mathrm{~h}$ & 59 & $76: 24$ \\
\hline 7 & $20 b$ & $\mathrm{Ph}$ & THF & $\mathrm{ZnBr}_{2}(0.4)$ & 0 & $16 \mathrm{~h}$ & 54 & $74: 26$ \\
\hline 8 & $20 b$ & $\mathrm{Ph}$ & THF & $\mathrm{ZnBr}_{2}(0.4)$ & -30 & $6 \mathrm{~d}$ & 39 & $65: 35$ \\
\hline 9 & $20 b$ & $\mathrm{Ph}$ & THF & $\mathrm{Zn}(\mathrm{OBz})_{2}(1.1)^{5}$ & 20 & $5 \mathrm{~h}$ & 36 & $64: 36$ \\
\hline
\end{tabular}

Notes: ${ }^{1}$ The crude aldehyde was thoroughly dried by azeotropic water removal with toluene and 1.1 equivalents of isocyanide and carboxylic acid were used. ${ }^{2}$ Overall yield of all stereoisomers over two steps. ${ }^{3}$ Determined by ${ }^{1} \mathrm{H}-\mathrm{NMR}$ in all cases and by HPLC as well (entries 5-9); the relative configuration of compounds 20 was determined as reported in the Supplementary Materials. ${ }^{4}$ Also minor amounts of trans isomers were detected. ${ }^{5}$ In these cases, no carboxylic acid was added in the MCR.

Moreover, the reaction turned out to be very slow ( $42 \mathrm{~h}$ vs. $1.5 \mathrm{~h}$ ), which also favored a partial epimerization of the aldehyde.

The addition of a substoichiometric amount of $\mathrm{ZnBr}_{2}$ had a beneficial effect on the d.r. and an accelerating effect on the rate ( $4 \mathrm{~h}$ vs. $31 \mathrm{~h}$ ), but the overall yield decreased (entry 3 ).

A problem we observed only in the $\mathrm{ZnBr}_{2}$ promoted Passerini is the formation of small amounts (usually less than 10\%) of a diastereomeric mixture of the so called 'truncated Passerini products' 23, which are not separable by chromatography from 20a, but can be acetylated in situ maintaining the overall d.r.. The formation of 'truncated' products in the presence of Lewis acids is not completely unexpected and is well documented [29].

Unfortunately, the separation of anti- and syn-20a is possible, but troublesome, and therefore we decided to use benzoic acid, instead of acetic acid, because the two epimers of $20 \mathbf{b}$ can be separated more easily by chromatography and by HPLC. The Passerini with no additives gave results like the one with acetic acid (entry 5). In the presence of $\mathrm{ZnBr}_{2}$, the rate increase was lower, compared to acetic acid (cfr. entries 3 and 6). We also studied the influence of the temperature: the reaction done at $0{ }^{\circ} \mathrm{C}$ resulted almost comparable to the one at $20^{\circ} \mathrm{C}$ (entries 7 and 6), while at $-30^{\circ} \mathrm{C}$ the rate dramatically decreased and a lower yield and d.r. were observed (entry 8 ).

Based on our recent results on another chiral bio-based aldehyde [10], we also tried a modification of the Passerini reaction using zinc dicarboxylates. Using $\mathrm{Zn}(\mathrm{OAc})_{2}$, the diastereoselectivity diminished considerably and the reaction became very slow, most likely because the $\mathrm{Zn}$ salt is poorly soluble (entry 4). Switching to zinc benzoate, the reaction rate increased noticeably but the yield was only modest and the d.r. was not satisfactory (entry 9). The unsatisfactory overall yield is most likely because recovery of $\mathbf{2 0}$ is incomplete. In our previous work, to liberate the Passerini product from 
zinc, a strongly acidic work-up was used, but here this acidic work-up is not possible, because of the presence of the very labile isopropylidene moiety.

After all, since the conditions using substoichiometric $\mathrm{ZnBr}_{2}$ (entries 6) were the best performing ones, we decided to study the scope of the reaction (Scheme 6) as summarized in Table 3.

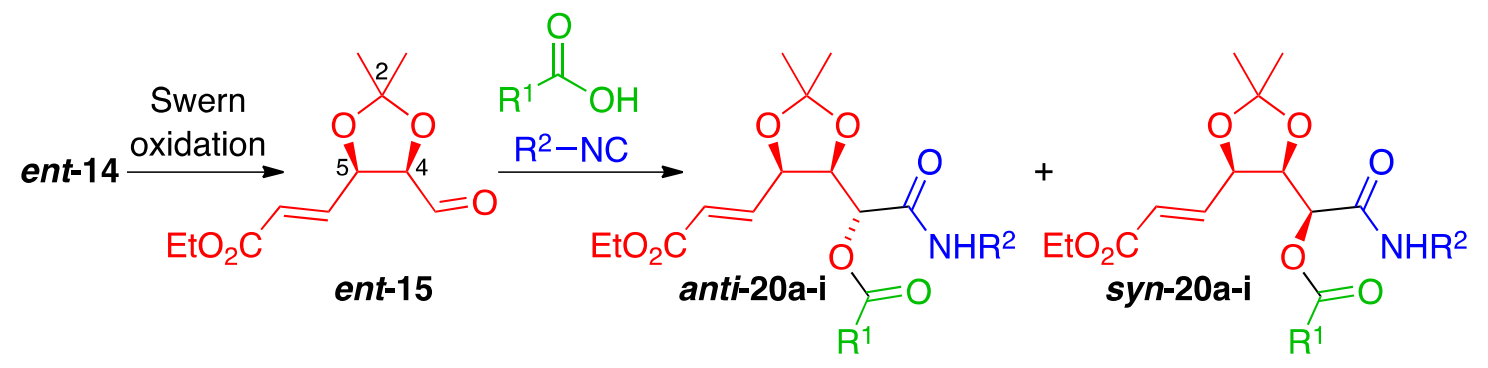

Scheme 6. Scope of the diastereoselective Passerini reaction.

Table 3. Scope of the $\mathrm{ZnBr}_{2}$ promoted Passerini.

\begin{tabular}{|c|c|c|c|c|c|}
\hline Entry $^{1}$ & Compd & $R^{1}$ & $\mathrm{R}^{2}$ & Yield $(\%)^{2}$ & anti-20: syn-20 \\
\hline 1 & $20 a$ & $\mathrm{Me}$ & $t-\mathrm{Bu}$ & 78 & $80: 20^{3}$ \\
\hline 2 & $20 \mathrm{~b}$ & $\mathrm{Ph}$ & $t-\mathrm{Bu}$ & 59 & $75: 25^{4,5}$ \\
\hline 3 & $20 c$ & $\mathrm{CH}_{2}=\mathrm{CH}\left(\mathrm{CH}_{2}\right)_{2}$ & $t-\mathrm{Bu}$ & 53 & $78: 22^{5}$ \\
\hline 4 & $20 d$ & $\mathrm{Me}$ & $2,3-(\mathrm{Me})_{2} \mathrm{C}_{6} \mathrm{H}_{3}$ & 51 & $93: 7^{3,4}$ \\
\hline 5 & $20 \mathrm{e}$ & $\mathrm{Me}$ & $-\mathrm{C}\left(\mathrm{CH}_{2} \mathrm{CH}=\mathrm{CH}_{2}\right)\left(\mathrm{CO}_{2} \mathrm{Et}\right)_{2}$ & 64 & $98: 2^{3,4}$ \\
\hline 6 & $20 f$ & $\mathrm{Ph}$ & $2,3-(\mathrm{Me})_{2} \mathrm{C}_{6} \mathrm{H}_{3}$ & 57 & $90: 10^{3}$ \\
\hline 7 & $20 \mathrm{~g}$ & $\mathrm{Ph}$ & $4-\mathrm{OBn}-\mathrm{C}_{6} \mathrm{H}_{4}\left(\mathrm{CH}_{2}\right)_{2}$ & 63 & $85: 15^{3}$ \\
\hline 8 & $20 \mathrm{~h}$ & $2-\mathrm{Me}-\mathrm{C}_{6} \mathrm{H}_{4}$ & $\mathrm{Bn}$ & 56 & $88: 12^{3}$ \\
\hline 9 & $20 \mathrm{i}$ & $\mathrm{MeOCH}_{2}$ & $c$-Hex & 64 & $84: 16^{3}$ \\
\hline
\end{tabular}

Notes: ${ }^{1}$ The crude aldehyde, obtained by Swern oxidation of ent-14, was thoroughly dried by azeotropic water removal with toluene and all reactions are performed at $20^{\circ} \mathrm{C}$ in THF, using 1.1 equivalents of carboxylic acid and isocyanide and 0.4 equivalents of $\mathrm{ZnBr}_{2}$; the average duration is around $20 \mathrm{~h}$. ${ }^{2}$ Yields over two steps. ${ }^{3} \mathrm{By}{ }^{1} \mathrm{H}-\mathrm{NMR}$. ${ }^{4}$ Only in these cases we observed the formation of a considerable amount of truncated Passerini products which were acylated in situ. ${ }^{5}$ By HPLC.

We used diverse isocyanides (primary, secondary, and tertiary aliphatic or aromatic) and carboxylic acids (aliphatic and aromatic). The overall yield over two steps (oxidation and Passerini) was good in all cases. The stereoselectivity ranges from moderate to excellent. We noticed that the stereoselectivity depends only marginally on the structure of the carboxylic acid. The structure of the isocyanide on the contrary influences more the stereoselectivity. In some cases we observed excellent d.r.s (>10:1), which are uncommon in intermolecular Passerini reactions of chiral aldehydes [4].

The role of $\mathrm{ZnBr}_{2}$ in promoting the stereoselectivity is not completely clear. On the previously described similar aldehyde 24 [9], we reported a model for explaining the stereoselectivity, based on the chelation of the metal by the carbonyl oxygen and the oxygen on carbon $\beta$ to the aldehyde (I, Scheme 7) [30]. On the other hand, the outcome of chiral aldehyde 26 [10] led us to revise our rationale, also because in that case a $\beta$-chelation is clearly not possible. In the light of the observation that, performing the Passerini reaction in $i \operatorname{Pr}_{2} \mathrm{O}$, the initially unsoluble $\mathrm{ZnBr}_{2}$ is partially dissolved upon addition of the isocyanide, we supposed a zinc coordination by it to give intermediate 28 . Therefore, in our previous paper, we proposed a concerted transition state, where $\mathbf{2 8}$ is also coordinated by the carbonyl oxygen. The formation of anti-27 was then rationalized through a preferred transition state II.

If a similar mechanism is working on aldehyde ent-14, a possible transition state explaining the prevailing formation of anti-20 would be III. 

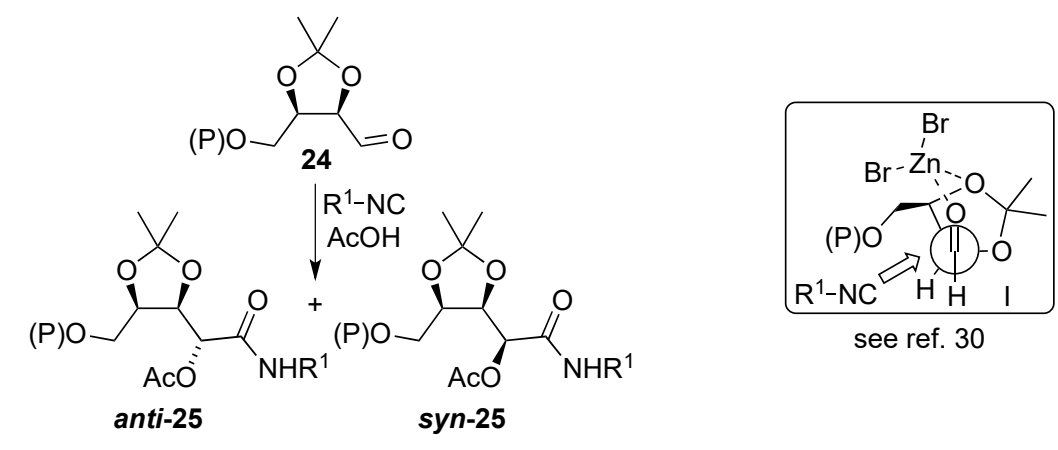

see ref. 30

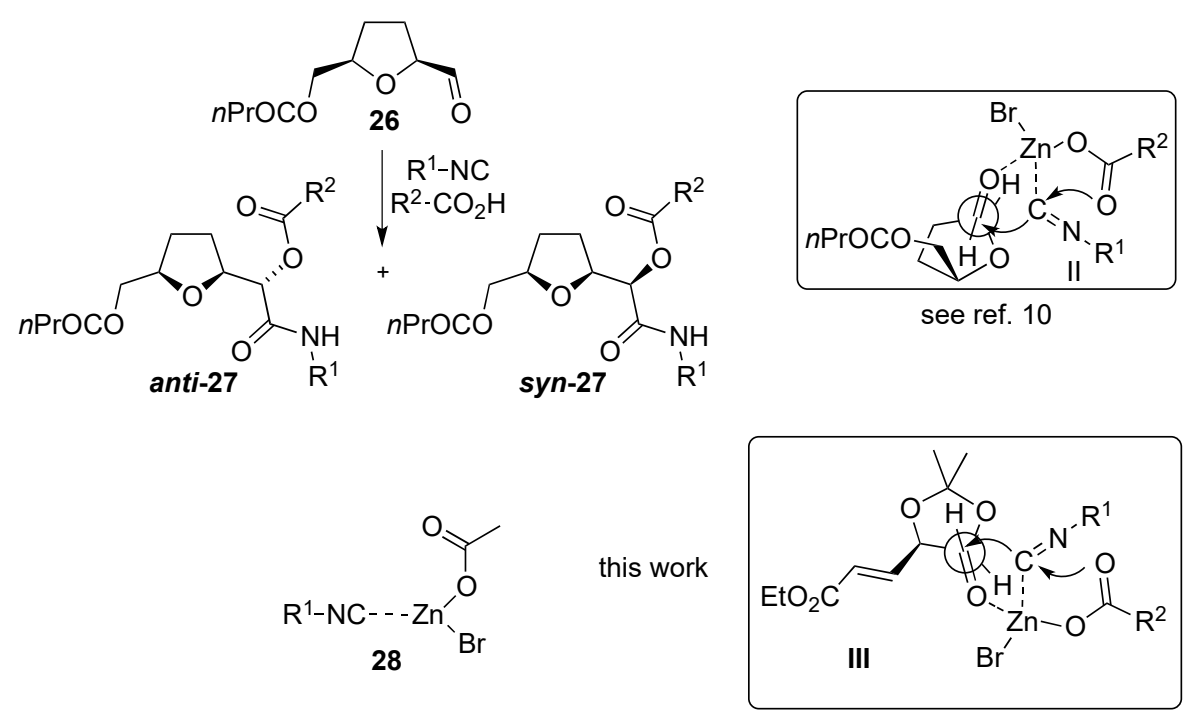

Scheme 7. Models for rationalization of stereoselectivity in the Passerini reaction.

\subsection{Elaboration of Passerini Products}

The presence of additional functional groups on the Passerini products allowed us to study different post-condensation transformations thus increasing the scaffold diversity. Aware of the easy intramolecular 5-exo-trig cyclization of $\mathbf{1 4}$ to give 16, we expected that basic solvolysis of 20a and 20b, would afford fast cyclization of the resulting secondary alcohol. The sequence was studied on both anti and syn diastereoisomers (Scheme 8), changing the reaction conditions to optimize yield and d.r. (Table 4).

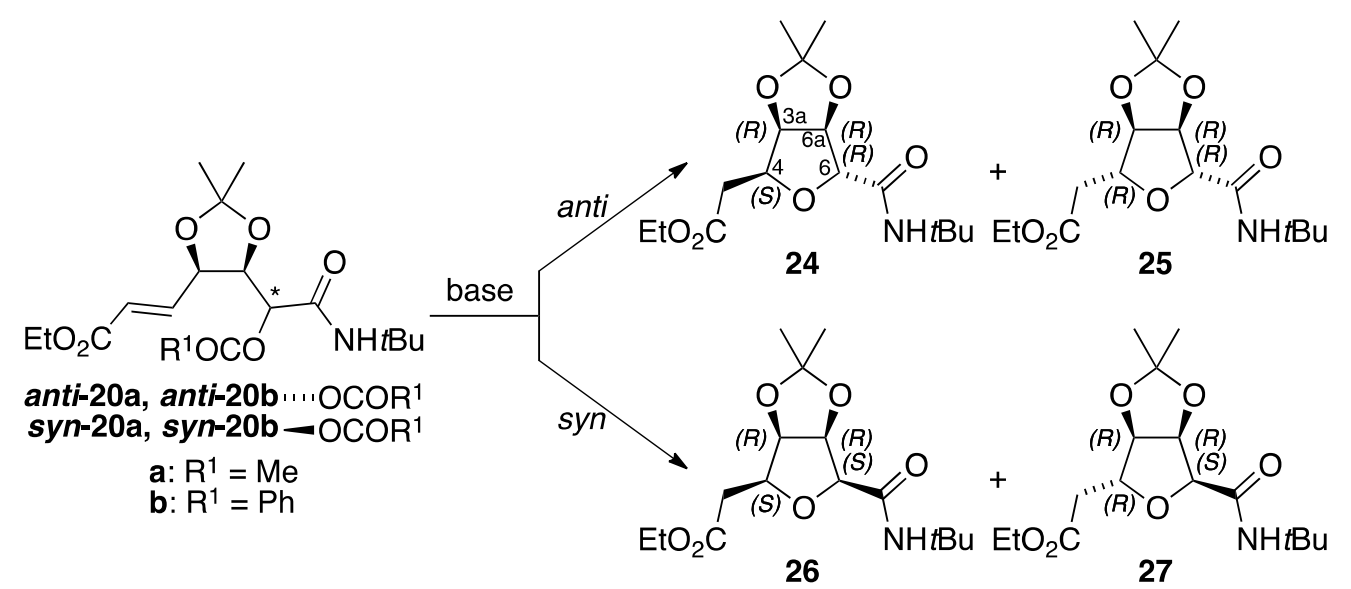

Scheme 8. Michael cyclization of both stereoisomers of Passerini products 20a and 20b. ${ }^{*}$ means both $R$

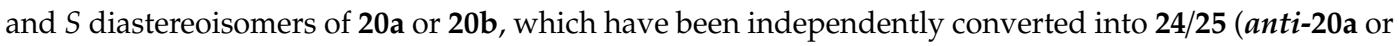
anti-20b) and 26/27 (syn-20a or syn-20b). 
Table 4. Michael cyclization of compounds 20a and 20b.

\begin{tabular}{|c|c|c|c|c|c|c|}
\hline Entry ${ }^{1}$ & Compd & Conditions $^{1}$ & Time (h) & Temperature & Yield (\%) & $\begin{array}{l}24: 25 \text { (from } a n t i)^{3,4} \\
26: 27(\text { from } s y n)^{3,4}\end{array}$ \\
\hline 1 & anti-20a & $\mathrm{KOH}(1 \mathrm{M})$ & 1 & r.t. & 33 & $91: 9$ \\
\hline 2 & anti-20a & $\operatorname{EtONa}(0.1 \mathrm{M})^{2}$ & 4 & r.t. & 58 & $90: 10$ \\
\hline 3 & anti-20b & $\operatorname{EtONa}(0.1 \mathrm{M})^{2}$ & 4 & r.t. & 73 & $92: 8$ \\
\hline 4 & anti-20b & $\operatorname{EtONa}(0.1 \mathrm{M})^{2}$ & 22 & $0^{\circ} \mathrm{C}$ & 83 & $89: 11$ \\
\hline 5 & anti-20b & $\mathrm{EtOH}: \mathrm{Et}_{3} \mathrm{~N} 5: 1: 1$ & 94 & r.t. $(67 \mathrm{~h}), 60^{\circ} \mathrm{C}(24 \mathrm{~h})$ & 74 & $82: 18$ \\
\hline 6 & syn-20a & $\mathrm{KOH}(1 \mathrm{M})$ & 1 & r.t. & 16 & $84: 16$ \\
\hline 7 & syn-20a & $\operatorname{EtONa}(0.1 \mathrm{M})^{2}$ & 5.5 & r.t. & 73 & $82: 18$ \\
\hline 8 & syn-20b & $\operatorname{EtONa}(0.1 \mathrm{M})^{2}$ & 6 & r.t. & 65 & $83: 17$ \\
\hline
\end{tabular}

Notes: ${ }^{1}$ All reactions were performed in EtOH as solvent. ${ }^{2}$ Prepared in situ from EtOH and Na. ${ }^{3}$ By ${ }^{1} \mathrm{H}-\mathrm{NMR} .{ }^{4}$

The reported relative configurations have been determined as reported in the Supplementary Materials.

The reaction was performed independently on the separated diastereoisomers of two Passerini products, differing by the acyl substituent $\left(R^{1}=M e, 20 a ; R^{1}=P h, 20 b\right)$, which of course afford the same tetrahydrofuran. All reactions turned out to be stereoselective, whatever the base employed. $\mathrm{KOH}$ was not satisfying (entries 1 and 6): despite the high reaction rate and the d.r.s which are among the best (entries 1 and 6), the isolated yield was rather poor.

Switching to sodium ethoxide [31], the reaction was slower and the d.r.s were comparable, but the yield increased significantly (entries 2 and 7). We texted the influence of the temperature as well: working a t $0{ }^{\circ} \mathrm{C}$ the reaction was slower, as expected, and we isolated the mixture of 24 and 25 in higher yield but no beneficial effect on the d.r. was observed (entry 4). As far as it concerns the starting acyl derivative, the cyclization of anti-20b affording 24 turned out to be more efficient than that of anti-20a (entries 3 and 2), while syn-20a provided 26 in higher yield but with the same d.r. as syn-20b (entries 7 and 8). Milder conditions employing $\mathrm{Et}_{3} \mathrm{~N}$ as base in $\mathrm{EtOH}$ required very long time and higher temperature which negatively affects either the yield and the d.r. We also performed a one-pot, three-step sequence: Swern oxidation/Passerini reaction/cyclization. The overall yield is almost comparable, but the purification is really complex because both the Passerini and the Michael reaction are not completely stereoselective, which renders this procedure unpractical.

The relative configuration of compounds $\mathbf{2 4 - 2 7}$ was determined by NMR studies as described in the Supplementary Materials.

The structure of $\mathbf{2 4}$ suggested the possibility to transform it into a bicyclic lactone, structurally correlated with styryllactones, such as (+)-goniofufurone 29a [32] and its diastereoisomer 29b [33] (Scheme 9), characterized by cytotoxic activity against several tumor cell lines [34].<smiles>O=C1C[C@H]2O[C@H](C(O)c3ccccc3)[C@@H](O)[C@H]2O1</smiles>

29a<smiles>O=C1C[C@H]2O[C@H](C(O)c3ccccc3)[C@@H](O)[C@H]2O1</smiles>

$29 b$

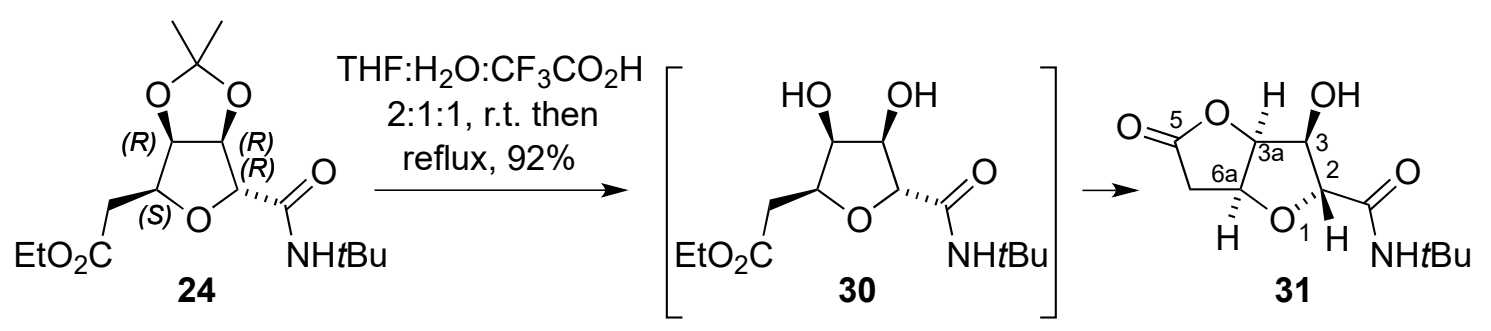

Scheme 9. Synthesis of (+)-goniofufurone analogues.

For this purpose, we cleaved the isopropylidene moiety by means of trifluoroacetic acid using the previously reported conditions ( $\mathrm{MeOH}: \mathrm{TFA}: \mathrm{H}_{2} \mathrm{O}$ 1.6:1:1, 87\%) [5] and then further increased the yield 
substituting $\mathrm{MeOH}$ with THF (THF:TFA: $\mathrm{H}_{2} \mathrm{O}$ 2:1:1, 97\%) although the reaction required more time (8 days vs. 3) [33] (Scheme 9).

The structure of 31 is partially rigid and, coupling MM2 calculations with NMR data, we were able to unambiguously establish the cis junction between the two $O$-heterocycles, and the relative trans relationship between the substituents on $C_{2}$ and $C_{3}$ (more details are reported in the Supplementary Materials). This assignment is also corroborated, especially for the relative configuration of ring junction, by comparison with the NMR spectra of $29 a$ and $29 \mathbf{b}$.

This confirmed the configuration of compound $\mathbf{2 4}$ and hence of $\mathbf{2 5 - 2 7}$ as well. Moreover, since the configuration of the stereogenic center generated during the Passerini reaction is not affected during the intramolecular Michael cyclization, we were able to assign the anti relative configuration to the prevailing stereoisomer in compounds $\mathbf{2 0}$, which is also supported by spectroscopic analogies with similar compounds.

Finally, we decided to exploit the two double bonds of $20 \mathrm{c}$ to perform a ring closing metathesis expecting to obtain 32 presumably as the $Z$ stereoisomer. Although the cyclization of medium size rings is expected to be difficult, there are already several reports in the literature on the formation of 9- [35] or 10-membered lactones [36] through this strategy, but all of them used only terminal double bonds. We attempted the RCM reaction on the major anti stereoisomer and performed different experiments using either first (33) or second-generation Grubbs catalysts (34), and working under high dilution conditions (Scheme 10). Unfortunately, we only recovered unreacted starting material.<smiles>C=CCCC(=O)O[C@H](C(=O)NCCCC)C1OC(C)(C)O[C@H]1/C=C/COCC</smiles><smiles>C=CCCC(=O)O[C@H](C(=O)NCCCC)[C@H]1OC(C)(C)O[C@H]1/C=C/CO[Y10](=O)[O-]</smiles>

Scheme 10. Attempted ring closing metathesis. 
Reasoning that the presence of the ester conjugated with the double bond could be a problem, we decided to reduce ester 18 to the allylic alcohol 35 [37], which was selectively protected as anisyl ether (36) and finally desilylated to afford 37, the precursor of the aldehyde to be involved in a Passerini reaction under the optimized conditions of Table 3. The MCR was only moderately stereoselective (77:13) and on anti-38 we tried again the RCM with both catalysts, working in high dilution (1 mM). Again, the expected product was not obtained, and we only isolated in low yield (15\%) the product of an intermolecular metathesis. One of the possible reasons of the failed cyclization is probably the presence of a substituted double bond which in many instances can hamper the RCM, though in the literature successful cyclizations involving a substituted double bond are well documented [38].

\section{Materials and Methods}

\subsection{General Information}

NMR spectra (see Supplementary Materials) were recorded on a Gemini $300 \mathrm{MHz}$ instrument (Varian, Palo Alto, CA, USA) at r.t. in $\mathrm{CDCl}_{3}$ at $300 \mathrm{MHz}\left({ }^{1} \mathrm{H}\right)$, and $75 \mathrm{MHz}\left({ }^{13} \mathrm{C}\right)$, using, as internal standard, TMS $\left({ }^{1} \mathrm{H}-\mathrm{NMR}\right.$ in $\left.\mathrm{CDCl}_{3}, 0.000 \mathrm{ppm}\right)$ or the central peak of $\mathrm{CDCl}_{3}\left({ }^{13} \mathrm{C}\right.$ in $\left.\mathrm{CDCl}_{3}, 77.02 \mathrm{ppm}\right)$. Chemical shifts are reported in ppm ( $\delta$ scale). Peak assignments were made with the aid of gCOSY and gHSQC experiments. In ABX system, the proton A is considered upfield and B downfield. IR spectra were recorded as solid, oil, or foamy samples, with the ATR (attenuated total reflectance) technique. TLC analyses were carried out on silica gel plates and viewed at UV $(\lambda=254 \mathrm{~nm}$ or $360 \mathrm{~nm})$ and developed with Hanessian stain (dipping into a solution of $\left(\mathrm{NH}_{4}\right)_{4} \mathrm{MoO}_{4} \cdot 4 \mathrm{H}_{2} \mathrm{O}(21 \mathrm{~g})$ and $\mathrm{Ce}\left(\mathrm{SO}_{4}\right)_{2} \cdot 4 \mathrm{H}_{2} \mathrm{O}(1 \mathrm{~g})$ in $\mathrm{H}_{2} \mathrm{SO}_{4}(31 \mathrm{~mL})$ and $\mathrm{H}_{2} \mathrm{O}(469 \mathrm{~mL})$ and warming $) . \mathrm{R}_{\mathrm{f}}$ values were measured after an elution of 5-7 cm. Column chromatography was done with the 'flash' methodology by using $220-400$ mesh silica. Petroleum ether $\left(40-60^{\circ} \mathrm{C}\right)$ is abbreviated as PE. All reactions employing dry solvents were carried out under nitrogen. After extractions, the aqueous phases were always re-extracted two times with the appropriate organic solvent, and the organic extracts were always dried over $\mathrm{Na}_{2} \mathrm{SO}_{4}$ and filtered before evaporation to dryness. HRMS: samples were analyzed with a Synapt G2 QToF mass spectrometer (Waters, Milford, MA, USA). MS signals were acquired from 50 to $1200 \mathrm{~m} / \mathrm{z}$ in either ESI positive or negative ionization mode. GC-MS were carried out using an HP-1 column (12 m long, $0.2 \mathrm{~mm}$ wide), electron impact at $70 \mathrm{eV}$, and a mass temperature of about $170{ }^{\circ} \mathrm{C}$. Only $\mathrm{m} / \mathrm{z}>33$ were detected. All analyses were performed (unless otherwise stated) with a constant He flow of $1.0 \mathrm{~mL} \mathrm{~min}{ }^{-1}$ with initial temp. $70^{\circ} \mathrm{C}$, init. time $2 \mathrm{~min}$, rate $20^{\circ} \mathrm{C} \mathrm{min}^{-1}$, final temp. $260{ }^{\circ} \mathrm{C}$, inj. temp. $250{ }^{\circ} \mathrm{C}$, det. temp. $280{ }^{\circ} \mathrm{C}$. HPLC analyses were carried out on a HP-1100 system (Agilent, Santa Clara, CA, USA) equipped with a HYDRO RP column $(150 \times 3 \mathrm{~mm}, 4 \mu)$ at $25^{\circ} \mathrm{C}$ with flow $=0.5 \mathrm{~mL} / \mathrm{min}$ and isocratic elution $\left(\mathrm{CH}_{3} \mathrm{CN} / \mathrm{H}_{2} \mathrm{O} 50: 50\right)$. Detection was done with UV at $220 \mathrm{~nm}$; b) C6 PHENYLIC RP column $(150 \times 3 \mathrm{~mm}, 4 \mu)$ at $25^{\circ} \mathrm{C}$ with flow $=0.34 \mathrm{~mL} / \mathrm{min}$ and gradient $\mathrm{H}_{2} \mathrm{O} / \mathrm{MeOH}$ 35:65 for $20 \mathrm{~min}$, then up to 30:70 until min 25. Then $\mathrm{H}_{2} \mathrm{O}: \mathrm{MeOH}$ 30:70. Detection was done with UV at $220 \mathrm{~nm}$.

\subsection{Syntheses}

((4R,5S)-2,2-dimethyl-1,3-dioxolane-4,5-diyl)dimethanol (11). Method A: from erythritol through a known procedure [21]. Method B: D-isoascorbic acid 9 was transformed into lactone 10, as previously reported [22]. Then, to a suspension of $\mathrm{LiAlH}_{4}(1.756 \mathrm{~g}, 46.50 \mathrm{mmol})$ in THF dry $(45 \mathrm{~mL})$ at $0{ }^{\circ} \mathrm{C}$, a solution of 10 (3.659 g, $23.15 \mathrm{mmol})$ in dry THF (32 mL) was added dropwise (40 min). The mixture was allowed to reach room temperature and stirred for $3 \mathrm{~h}$. Then it was cooled to $0{ }^{\circ} \mathrm{C}$ and carefully quenched with Fieser method: deionized water $(1.7 \mathrm{~mL}), \mathrm{NaOH}(15 \%, 1.7 \mathrm{~mL})$ and deionized water $(5.1 \mathrm{~mL})$ were sequentially added dropwise. The mixture was stirred until a white suspension was obtained, which was filtered through a Celite cake. The Celite was washed several times with boiling $\mathrm{THF}$ and the filtrate was concentrated. The residue was triturated with $\mathrm{Et}_{2} \mathrm{O}$ to afford 11 (3.082 g, $82 \%$ yield) as a white solid, which analytical data are agree with the reported ones [21]. 
Ethyl 3-((4S,5R)-5-(acetoxymethyl)-2,2-dimethyl-1,3-dioxolan-4-yl)acrylate (13). (a) Swern oxidation: to a solution of dry DMSO $(87 \mu \mathrm{L}, 1.22 \mathrm{mmol})$ in dry $\mathrm{CH}_{2} \mathrm{Cl}_{2}(2.9 \mathrm{~mL})$, a solution of oxalyl chloride in dry $\mathrm{CH}_{2} \mathrm{Cl}_{2}(2.0 \mathrm{M}, 515 \mu \mathrm{L})$ was added at $-78{ }^{\circ} \mathrm{C}$. After 10 min stirring a solution of alcohol 2 (100 $\mathrm{mg}, 0.49 \mathrm{mmol})$ in dry $\mathrm{CH}_{2} \mathrm{Cl}_{2}(2 \mathrm{~mL})$ was added dropwise, and the solution was stirred for $10 \mathrm{~min}$. Then $\mathrm{Et}_{3} \mathrm{~N}(320 \mu \mathrm{L}, 2.30 \mathrm{mmol})$ was added and the solution was stirred for $1 \mathrm{~h}$ at $-78^{\circ} \mathrm{C}$. The reaction was quenched by addition of $5 \%$ aq. $\left(\mathrm{NH}_{4}\right) \mathrm{H}_{2} \mathrm{PO}_{4}(10 \mathrm{~mL}$, added with $1 \mathrm{~N} \mathrm{HCl}$ solution to reach a final $\mathrm{pH}=4)$ and extracted with $\mathrm{Et}_{2} \mathrm{O}(3 \times 10 \mathrm{~mL})$. The combined organic layers were washed with $5 \%$ aq. $\mathrm{NaHCO}_{3}(10 \mathrm{~mL})$ and brine $(10 \mathrm{~mL})$, dried $\left(\mathrm{Na}_{2} \mathrm{SO}_{4}\right)$, and concentrated to afford the expected aldehyde as a yellow oil, which was used as such for the next reaction. (b) Horner-Wadsworth- Emmons reaction: to a suspension of $\mathrm{LiCl}(31 \mathrm{mg}, 0.73 \mathrm{mmol})$ and $3 \AA$ molecular sieves $(10 \mathrm{mg} / 0.1 \mathrm{mmol}$ aldehyde $)$ in dry MeCN $(5.4 \mathrm{~mL})$ triethyl phosphonoacetate $(165 \mu \mathrm{L}, 0.73 \mathrm{mmol})$, diisopropylethylamine $(85 \mu \mathrm{L}$, $0.49 \mathrm{mmol}$ ) and the crude aldehyde were added. The reaction was stirred at room temperature for $28 \mathrm{~h}$, then it was filtered on a Celite cake. The solution was diluted with saturated aq. $\mathrm{NH}_{4} \mathrm{Cl}(10 \mathrm{~mL})$ and extracted with $\mathrm{Et}_{2} \mathrm{O}(3 \times 10 \mathrm{~mL})$. The combined organic layers were washed with brine $(10 \mathrm{~mL})$, dried, and concentrated to afford a 95:5 E:Z mixture ( $\left.{ }^{1} \mathrm{H}-\mathrm{NMR}\right)$. The residue was purified by chromatography (PE:Et ${ }_{2} \mathrm{O}$ 7:3) to afford $\boldsymbol{E}-\mathbf{1 3}$ (108 mg, 81\% yield from 11) and $\mathbf{Z - 1 3}(4.9 \mathrm{mg}$, 5\% yield from 11) as pale yellow oils. $E-13: \mathrm{R}_{\mathrm{f}}=0.22\left(\mathrm{PE}: \mathrm{Et}_{2} \mathrm{O} 7: 3\right) .{ }^{1} \mathrm{H}-\mathrm{NMR}\left(\mathrm{CDCl}_{3}\right): \delta 6.85(\mathrm{dd}, J=15.6,5.5 \mathrm{~Hz}, 1 \mathrm{H}$, $\left.\mathrm{CH}=\mathrm{CHCO}_{2} \mathrm{Et}\right), 6.15\left(\mathrm{dd}, J=15.6,1.6 \mathrm{~Hz}, 1 \mathrm{H}, \mathrm{CHCO}_{2} \mathrm{Et}\right), 4.83(\mathrm{ddd}, J=6.8,5.5,1.6 \mathrm{~Hz}, 1 \mathrm{H}, \mathrm{H}-4), 4.46$ $(\mathrm{dt}, J=6.8,5.3 \mathrm{~Hz}, 1 \mathrm{H}, \mathrm{H}-5), 4.21\left(\mathrm{q}, J=7.1 \mathrm{~Hz}, 2 \mathrm{H}, \mathrm{CH}_{2} \mathrm{CH}_{3}\right), 4.09,3.95$ (AB part of an ABX syst., $\left.J_{\mathrm{AB}}=10.0 \mathrm{~Hz}, J_{\mathrm{AX}}=4.1 \mathrm{~Hz}, J_{\mathrm{BX}}=4.9 \mathrm{~Hz}, 2 \mathrm{H}, \mathrm{CH}_{2} \mathrm{OAc}\right), 2.07\left(\mathrm{~s}, 3 \mathrm{H}, \mathrm{CH}_{3} \mathrm{CO}\right), 1.53,1.40(2 \mathrm{~s}, 2 \times 3 \mathrm{H}$, $\left.\left(\mathrm{CH}_{3}\right)_{2} \mathrm{C}\right), 1.30\left(\mathrm{t}, J=7.1 \mathrm{~Hz}, 3 \mathrm{H}, \mathrm{CH}_{3} \mathrm{CH}_{2}\right) . \mathrm{Z}-13: \mathrm{R}_{\mathrm{f}}=0.38\left(\mathrm{PE}_{\mathrm{Et}} \mathrm{O}\right.$ 7:3). ${ }^{1} \mathrm{H}-\mathrm{NMR}\left(\mathrm{CDCl}_{3}\right): \delta 6.29$ $\left(\mathrm{dd}, J=11.6,7.0 \mathrm{~Hz}, 1 \mathrm{H}, \mathrm{CH}=\mathrm{CHCO}_{2} \mathrm{Et}\right), 5.94\left(\mathrm{dd}, J=11.6,1.7 \mathrm{~Hz}, 1 \mathrm{H}, \mathrm{CHCO}_{2} \mathrm{Et}\right), 5.65(\mathrm{td}, J=7.2$, $1.7 \mathrm{~Hz}, 1 \mathrm{H}, \mathrm{H}-4), 4.69$ (td, $J=7.2,3.3 \mathrm{~Hz}, 1 \mathrm{H}, \mathrm{H}-5), 4.18\left(\mathrm{q}, J=7.2 \mathrm{~Hz}, 2 \mathrm{H}, \mathrm{CH}_{2} \mathrm{CH}_{3}\right), 4.12(\mathrm{dd}, J=11.7$, $3.4 \mathrm{~Hz}, 1 \mathrm{H}, \mathrm{CHHOAc}), 3.87(\mathrm{dd}, J=11.7,6.9 \mathrm{~Hz}, 1 \mathrm{H}, \mathrm{CHHOAc}), 2.07\left(\mathrm{~s}, 3 \mathrm{H}, \mathrm{CH}_{3} \mathrm{CO}\right), 1.53,1.40(2 \mathrm{~s}$, $\left.2 \times 3 \mathrm{H},\left(\mathrm{CH}_{3}\right)_{2} \mathrm{C}\right), 1.30\left(\mathrm{t}, J=7.2 \mathrm{~Hz}, 3 \mathrm{H}, \mathrm{CH}_{3} \mathrm{CH}_{2}\right)$.

Ethyl 2-((3aS,4S,6aR)-2,2-dimethyltetrahydrofuro[3,4-d][1,3]dioxol-4-yl)acetate (anti-16) and Ethyl 2-((3aS,4R, 6aR)-2,2-dimethyltetrahydrofuro[3,4-d][1,3]dioxol-4-yl)acetate (syn-16). A solution of $\mathbf{1 3}$ (50 mg, $0.18 \mathrm{mmol})$ in $\mathrm{EtOH}(1 \mathrm{~mL})$ was treated with $\mathrm{H}_{2} \mathrm{O}(200 \mu \mathrm{L})$ and $\mathrm{Et}_{3} \mathrm{~N}(200 \mu \mathrm{L})$ and stirred for 6 days at room temperature. The reaction was quenched with saturated aq. $\mathrm{NH}_{4} \mathrm{Cl}(10 \mathrm{~mL})$ and extracted with $\mathrm{Et}_{2} \mathrm{O}$ $(3 \times 10 \mathrm{~mL})$. The combined organic layers were washed with brine $(10 \mathrm{~mL})$, dried, and concentrated. The residue was purified by chromatography (PE: $\mathrm{Et}_{2} \mathrm{O} 6: 4$ to $\left.\mathrm{Et}_{2} \mathrm{O}+1 \% \mathrm{EtOH}\right)$ to give 16 (26 mg, $62 \%$ yield, colorless oil)) as an inseparable mixture of syn and anti stereoisomers (74:26 by GC-MS). $\mathrm{R}_{\mathrm{f}}=0.30$ (PE: $\left.\mathrm{Et}_{2} \mathrm{O} 1: 1\right)$. The individual NMR spectra were extrapolated from the NMR spectra of a 74:26 (syn:anti) mixture and are in agreement with the previously reported [31], where however the complete NMR spectra of syn-16 are not available. Syn-16: ${ }^{1} \mathrm{H}-\mathrm{NMR}\left(\mathrm{CDCl}_{3}\right): \delta 4.78(\mathrm{dd}, J=6.1,3.4 \mathrm{~Hz}$, $1 \mathrm{H}, \mathrm{H}-6 \mathrm{a}), 4.71(\mathrm{dd}, J=6.1,3.7 \mathrm{~Hz}, 1 \mathrm{H}, \mathrm{H}-3 \mathrm{a}), 4.17\left(\mathrm{q}, J=7.1 \mathrm{~Hz}, 2 \mathrm{H}, \mathrm{CH}_{2} \mathrm{CH}_{3}\right), 4.01(\mathrm{~d}, J=10.7 \mathrm{~Hz}, 1 \mathrm{H}$, H-6), $3.86(\mathrm{td}, J=7.2,3.7 \mathrm{~Hz}, 1 \mathrm{H}, \mathrm{H}-4), 3.49$ (dd, $J=10.7,3.6 \mathrm{~Hz}, 1 \mathrm{H}, \mathrm{H}-6) ; 2.77,2.75$ (AB part of an ABX system, $\left.\mathrm{J}_{\mathrm{AB}}=16.7 \mathrm{~Hz}, \mathrm{~J}_{\mathrm{AX}}=7.0 \mathrm{~Hz}, \mathrm{~J}_{\mathrm{BX}}=6.4 \mathrm{~Hz}, 2 \mathrm{H}, \mathrm{CH}_{2} \mathrm{CO}_{2} \mathrm{Et}\right), 1.47,1.33\left(2 \mathrm{~s}, 2 \times 3 \mathrm{H},\left(\mathrm{CH}_{3}\right)_{2} \mathrm{C}\right)$, $1.27\left(\mathrm{t}, J=7.0 \mathrm{~Hz}, 3 \mathrm{H}, \mathrm{CH}_{3} \mathrm{CH}_{2}\right) .{ }^{13} \mathrm{C}-\mathrm{NMR}\left(\mathrm{CDCl}_{3}\right): \delta 171.2(\mathrm{C}=\mathrm{O}), 112.2(\mathrm{C}-2), 81.1(\mathrm{C}-6 \mathrm{a}), 80.8(\mathrm{C}-3 \mathrm{a})$, $78.3(\mathrm{C}-4), 72.7(\mathrm{C}-6), 60.8\left(\mathrm{CH}_{2} \mathrm{CH}_{3}\right), 33.8\left(\mathrm{CH}_{2} \mathrm{CO}_{2} \mathrm{Et}\right), 26.0,24.9\left(\left(\mathrm{CH}_{3}\right)_{2} \mathrm{C}\right), 14.2\left(\mathrm{CH}_{3} \mathrm{CH}_{2}\right)$. Anti-16: ${ }^{1} \mathrm{H}-\mathrm{NMR}: \delta 4.82(\mathrm{ddd}, J=6.0,4.2,1.2 \mathrm{~Hz}, 1 \mathrm{H}, \mathrm{H}-6 \mathrm{a}), 4.57(\mathrm{dd}, J=6.0,1.6 \mathrm{~Hz}, 1 \mathrm{H}, \mathrm{H}-3 \mathrm{a}), 4.45$ (td, $J=7.1$, $1.6 \mathrm{~Hz}, 1 \mathrm{H}, \mathrm{H}-4) ; 4.17$ (q, J = 7.1 Hz, 2H, $\left.\mathrm{CH}_{2} \mathrm{CH}_{3}\right), 3.99$ (dd, $\left.J=10.7,1.5 \mathrm{~Hz}, 1 \mathrm{H}, \mathrm{H}-6\right) ; 3.49-3.43$ (m, 1H, H-6), $2.48\left(\mathrm{~d}, J=7.1 \mathrm{~Hz}, 2 \mathrm{H}, \mathrm{CH}_{2} \mathrm{CO}_{2} \mathrm{Et}\right), 1.52,1.33\left(2 \mathrm{~s}, 2 \times 3 \mathrm{H},\left(\mathrm{CH}_{3}\right)_{2} \mathrm{C}\right), 1.27(\mathrm{t}, J=7.0 \mathrm{~Hz}$, $\left.3 \mathrm{H}, \mathrm{CH}_{3} \mathrm{CH}_{2}\right) .{ }^{13} \mathrm{C}-\mathrm{NMR}\left(\mathrm{CDCl}_{3}\right): \delta 170.4(\mathrm{C}=\mathrm{O}), 113.0(\mathrm{C}-2), 84.5(\mathrm{C}-3 \mathrm{a}), 81.1$ (C-4), $81.0(\mathrm{C}-6 \mathrm{a}), 72.3$ (C-6), $60.6\left(\mathrm{CH}_{2} \mathrm{CH}_{3}\right), 36.4\left(\mathrm{CH}_{2} \mathrm{CO}_{2} \mathrm{Et}\right), 26.6,25.0\left(\left(\mathrm{CH}_{3}\right)_{2} \mathrm{C}\right), 14.2\left(\mathrm{CH}_{3} \mathrm{CH}_{2}\right)$.

((4R,5S)-5-((tert-butyldimethylsilyl)oxy)methyl)-2,2-dimethyl-1,3-dioxolan-4-yl)methanol (17). It was prepared in two steps from 2 , as previously described, as a pale yellow oil in $98 \%$ overall yield [23]. $R_{\mathrm{f}}=0.60$ (PE:Et $\left.{ }_{2} \mathrm{O} 1: 1\right) \cdot[\alpha]^{23}{ }_{\mathrm{D}}=+3.73\left(\mathrm{c}=1.03, \mathrm{CHCl}_{3}\right) . \mathrm{HRMS}(\mathrm{ESI}+): \mathrm{m} / z 299.1661\left(\mathrm{M}+\mathrm{Na}^{+}\right) \cdot \mathrm{C}_{13} \mathrm{H}_{28} \mathrm{O}_{4} \mathrm{SiNa}$ requires: 299.1649. The other analytical data agree with the reported ones. 
(E)-Ethyl 3-((4R,5S)-5-(((tert-butyldimethylsilyl)oxy)methyl)-2,2-dimethyl-1,3-dioxolan-4-yl)acrylate (18). It was prepared in two steps from 17, as previously described, as a colorless oil in $94 \%$ overall yield and a 97:3 E:Z ratio [23]. $\mathrm{R}_{\mathrm{f}}=0.76\left(\mathrm{PE}: \mathrm{Et}_{2} \mathrm{O} 6: 4\right) .[\alpha]^{23} \mathrm{D}=+12.03\left(\mathrm{c}=0.97, \mathrm{CHCl}_{3}\right)$. The analytical data agree with the reported ones.

(E)-ethyl 3-((4R,5S)-5-(hydroxymethyl)-2,2-dimethyl-1,3-dioxolan-4-yl)acrylate (ent-14). A solution of 18 (803 mg, $2.33 \mathrm{mmol})$ was dissolved in THF/pyridine $(24.6 \mathrm{~mL}, 65: 35)$ and cooled to $0{ }^{\circ} \mathrm{C}$. Then Olah's reagent (hydrogen fluoride pyridine complex) $(\sim 70 \% \mathrm{HF}, 2.1 \mathrm{~mL}, \sim 81 \mathrm{mmol})$ was added and the reaction was stirred at the same temperature for 3 days. The reaction was quenched with saturated aq. $\mathrm{NH}_{4} \mathrm{Cl}$ $(20 \mathrm{~mL})$ and extracted with $\mathrm{Et}_{2} \mathrm{O}(3 \times 20 \mathrm{~mL})$. The combined organic layers were washed with water $(4$ $\times 25 \mathrm{~mL})$ and brine $(20 \mathrm{~mL})$, dried and concentrated. The residue was purified by chromatography (PE:Et $\left.{ }_{2} \mathrm{O} 3: 7\right)$ to give ent-14 (532 mg, 99\% yield) as a colorless oil The analytical data are in agreement with the reported ones [39]. $\mathrm{R}_{\mathrm{f}}=0.25\left(\mathrm{PE} / \mathrm{Et}_{2} \mathrm{O} 3: 7\right) .[\alpha]^{24} \mathrm{D}=-33.32\left(\mathrm{c}=1.14, \mathrm{CHCl}_{3}\right)$.

General procedure for the synthesis of Passerini products (20a-i, 38). (a) Swern oxidation: the same procedure described above for the oxidation of 2 was followed, starting from ent-14. The crude yellow oil was thoroughly dried by azeotropic water removal and then it was directly employed in the next Passerini reaction. (b) General procedure the for the Passerini reaction under classic conditions (method A): a solution of crude aldehyde ent-15 in dry $\mathrm{CH}_{2} \mathrm{Cl}_{2}$ (20a) or THF (20a, 20b, 20c, 38) (1 M) at $20{ }^{\circ} \mathrm{C}$ was treated with the appropriate carboxylic acid (1.1 eq) and isocyanide (1.1 eq) and stirred until complete. The solution was concentrated and purified by chromatography. (c) General procedure for the Passerini reaction with $\mathrm{ZnBr}_{2}(20 \mathrm{a}-\mathbf{i}, 38)$ (method B): a solution of crude ent-14 (2 M in THF), carboxylic acid (1.1 equiv.) and isocyanide (1.1 equiv.) were added to a solution of $\mathrm{ZnBr}_{2}$ (0.4 equiv.) in dry THF (1 M) at $20{ }^{\circ} \mathrm{C}$. The resulting solution was stirred at $20{ }^{\circ} \mathrm{C}$ until complete. After quenching with saturated aq. $\mathrm{NH}_{4} \mathrm{Cl}$, an extraction with ethyl acetate was performed. The combined organic layers were washed with $5 \%$ aq. $\mathrm{NaHCO}_{3}$, dried and concentrated. The residue was purified by chromatography.

Ethyl (E)-3-((4R,5R)-5-((R)-1-acetoxy-2-(tert-butylamino)-2-oxoethyl)-2,2-dimethyl-1,3-dioxolan-4-yl)acrylate (20a). It was prepared by method $\mathrm{A}$ in $\mathrm{CH}_{2} \mathrm{Cl}_{2}$ (overall yield anti + syn: $92 \%$ from ent-14, d.r. 59:41) or in THF (overall yield anti + syn: 97\% from ent-14, d.r. 51:49), and by method B (overall yield anti + syn: $78 \%$ from ent-14, d.r. 80:20). Chromatography was performed with $\mathrm{PE}: \mathrm{CH}_{2} \mathrm{Cl}_{2}: \mathrm{Et}_{2} \mathrm{O}$ 3:1:1. The separation of the two diastereoisomers was possible only after repeated chromatographies. Anti-20a: colorless oil. $\mathrm{R}_{\mathrm{f}}=0.68\left(\mathrm{PE}: \mathrm{Et}_{2} \mathrm{O} 2: 8\right) .[\alpha]^{24} \mathrm{D}=-50.26\left(\mathrm{c}=0.815, \mathrm{CHCl}_{3}\right)$. IR (ATR): $v_{\max } 3355$, 2981, 2938, 1751, 1719, 1682, 1525, 1456, 1368, 1303, 1253, 1210, 1179, 1161, 1122, 1060, 1033, 982, 938, 883, 861, 795. GC-MS: $\mathrm{R}_{\mathrm{t}} 9.89 \mathrm{~min}: \mathrm{m} / \mathrm{z} 356\left(\mathrm{M}^{+}\right.$- 15, 0.2), 198 (5.1), 172 (6.8), 171 (8.6), 170 (12), 154 (7.3), 152 (8.6), 151 (7.0), 143 (11), 131 (5.3), 130 (17), 129 (6.7), 126 (14), 125 (13), 113 (6.1), 112 (30), 109 (7.9), 108 (5.5), 101 (8.1), 97 (24), 85 (15), 84 (43), 83 (5.6), 81 (10), 69 (6.0), 59 (17), 58 (43), 57 (52), 56 (5.1), 55 (10), 43 (100), 42 (6.3), 41 (23), 39 (9.9). ${ }^{1} \mathrm{H}-\mathrm{NMR}\left(\mathrm{CDCl}_{3}\right): \delta 6.89(\mathrm{dd}, J=15.6,5.4 \mathrm{~Hz}, 1 \mathrm{H}, \mathrm{CHCH}=\mathrm{CH}), 6.12$ $(\mathrm{dd}, J=15.6,1.6 \mathrm{~Hz}, 1 \mathrm{H}, \mathrm{O}=\mathrm{CCH}=\mathrm{CH}), 5.82($ broad s, $1 \mathrm{H}, \mathrm{NH}), 4.87(\mathrm{ddd}, J=6.7,5.4,1.6 \mathrm{~Hz}, 1 \mathrm{H}, \mathrm{H}-4)$, $4.85(\mathrm{~d}, J=7.9 \mathrm{~Hz}, 1 \mathrm{H}, \mathrm{CHOAc}), 4.66(\mathrm{dd}, J=7.9,6.5 \mathrm{~Hz}, 1 \mathrm{H}, \mathrm{H}-5), 4.19\left(\mathrm{q}, J=7.1 \mathrm{~Hz}, 2 \mathrm{H}, \mathrm{CH}_{2} \mathrm{CH}_{3}\right)$, $2.10\left(\mathrm{~s}, 3 \mathrm{H}, \mathrm{CH}_{3} \mathrm{CO}\right), 1.51,1.38\left(2 \mathrm{~s}, 2 \times 3 \mathrm{H}, \mathrm{C}\left(\mathrm{CH}_{3}\right)_{2}\right), 1.32\left(\mathrm{~s}, 9 \mathrm{H}, \mathrm{C}\left(\mathrm{CH}_{3}\right)_{3}\right), 1.27(\mathrm{t}, J=7.1 \mathrm{~Hz}, 3 \mathrm{H}$, $\left.\mathrm{CH}_{2} \mathrm{CH}_{3}\right) .{ }^{13} \mathrm{C}-\mathrm{NMR}\left(\mathrm{CDCl}_{3}\right): \delta 169.4,166.0,165.8(\mathrm{C}=\mathrm{O}), 141.3(\mathrm{CHCH}=\mathrm{C}), 122.5(\mathrm{CHCH}=\mathrm{CH}), 109.6$

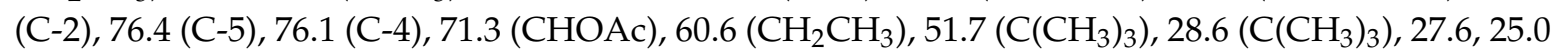
$\left(\mathrm{CH}_{3} \mathrm{CCH}_{3}\right), 20.6\left(\mathrm{CH}_{3} \mathrm{CO}\right), 14.2\left(\mathrm{CH}_{3} \mathrm{CH}_{2}\right)$. HRMS (ESI+): m/z $394.1835\left(\mathrm{M}+\mathrm{Na}^{+}\right) . \mathrm{C}_{18} \mathrm{H}_{29} \mathrm{NNaO}_{7}$ requires: 394.1836. Syn-20a: colorless oil. $\mathrm{R}_{\mathrm{f}}=0.79\left(\mathrm{PE}: \mathrm{Et}_{2} \mathrm{O} 2: 8\right) .[\alpha]^{24}{ }_{\mathrm{D}}=-62.52\left(\mathrm{c}=0.90, \mathrm{CHCl}_{3}\right)$. IR (ATR): $v_{\max } 3361,2981,2937,2875,1751,1719,1682,1525,1456,1368,1303,1254,1210,1178,1161$, 1121, 1060, 1033, 983, 938, 883, 862, 795, 661. GC-MS: $\mathrm{R}_{\mathrm{t}} 9.79 \mathrm{~min}: \mathrm{m} / \mathrm{z} 356\left(\mathrm{M}^{+}-15,0.8\right), 198(12), 172$ (6.0), 171 (8.3), 170 (9.1), 154 (5.1), 152 (9.9), 151 (5.2), 143 (8.6), 198 (12), 172 (6.0), 171 (8.3), 170 (9.1), 154 (5.1), 152 (9.9), 151 (5.2), 143 (8.6), 131 (6.8), 130 (19), 129 (7.2), 126 (12), 125 (11), 113 (5.7), 112 (27), 109 (6.0), 108 (5.3), 101 (8.5), 97 (22), 85 (15), 84 (36), 83 (5.4), 81 (9.0), 69 (6.3), 59 (16), 58 (44), 57 (49), 55 (11), 43 (100), 42 (6.3), 41 (22), 39 (9.1). ${ }^{1} \mathrm{H}-\mathrm{NMR}\left(\mathrm{CDCl}_{3}\right): \delta 6.81$ (dd, J = 15.6, $\left.5.6 \mathrm{~Hz}, 1 \mathrm{H}, \mathrm{CH}=\mathrm{CHCO}\right)$, $6.10(\mathrm{dd}, J=15.6,1.5 \mathrm{~Hz}, 1 \mathrm{H}, \mathrm{CH}=\mathrm{CHCO}), 5.86($ broad s, $1 \mathrm{H}, \mathrm{NH}), 4.94(\mathrm{~d}, J=5.7 \mathrm{~Hz}, 1 \mathrm{H}, \mathrm{CHOAc})$, 
4.89 (ddd, $J=7.0,5.6,1.5 \mathrm{~Hz}, \mathrm{H}-4), 4.75(\mathrm{dd}, J=7.0,5.7 \mathrm{~Hz}, \mathrm{H}-5), 4.20\left(\mathrm{q}, J=7.1 \mathrm{~Hz}, 2 \mathrm{H}, \mathrm{CH}_{2} \mathrm{CH}_{3}\right)$,

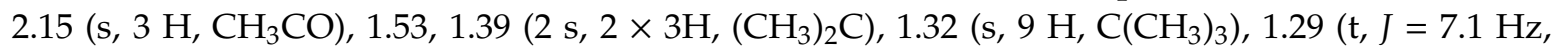
$\left.\mathrm{CH}_{3} \mathrm{CH}_{2}\right) .{ }^{13} \mathrm{C}-\mathrm{NMR}\left(\mathrm{CDCl}_{3}\right): \delta 170.1,166.2,165.6(\mathrm{C}=\mathrm{O}), 141.8(\mathrm{CHCH}=\mathrm{C}), 123.5(\mathrm{CHCH}=\mathrm{CH}), 109.7$

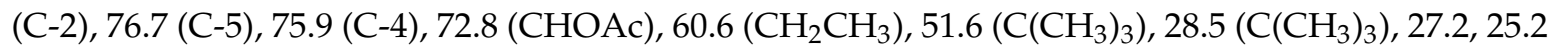
$\left(\mathrm{CH}_{3} \mathrm{CCH}_{3}\right), 21.0\left(\mathrm{CH}_{3} \mathrm{CO}\right), 14.2\left(\mathrm{CH}_{3} \mathrm{CH}_{2}\right)$. HRMS (ESI+): $\mathrm{m} / \mathrm{z} 394.1830\left(\mathrm{M}+\mathrm{Na}^{+}\right) . \mathrm{C}_{18} \mathrm{H}_{29} \mathrm{NNaO}_{7}$ requires: 394.1836 .

Ethyl (E)-3-((4R,5R)-5-((R)-1-benzoyloxy-2-(tert-butylamino)-2-oxoethyl)-2,2-dimethyl-1,3-dioxolan-4-yl)acrylate (20b). It was prepared by method A in THF (overall yield ant $i$ syn: $97 \%$ from ent-14, d.r. 45:55), and by method B (overall yield anti + syn: 59\% from ent-14, d.r. 75:25). Chromatography was performed with

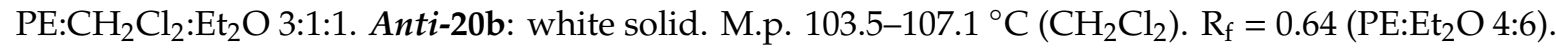
$\mathrm{R}_{\mathrm{f}}=0.25\left(\mathrm{PE} / \mathrm{Et}_{2} \mathrm{O} 3: 7\right),[\alpha]^{24}{ }_{\mathrm{D}}=-53.53\left(\mathrm{c}=0.97, \mathrm{CHCl}_{3}\right)$. IR (ATR): $v_{\max } 3338,3077,2977,1712,1669$, 1602, 1535, 1453, 1368, 1294, 1253, 1238, 1218, 1179, 1161, 1114, 1068, 1047, 1029, 1001, 989, 881, 819, 804, 787, 760, 709, 686, 671, 626. GC-MS: $\mathrm{R}_{\mathrm{t}} 11.91 \mathrm{~min}: \mathrm{m} / \mathrm{z} 418$ (M+ - 15, 2.2), 130 (5.2), 112 (8.9), 106 (7.0), 105 (100), 84 (12), 77 (16), 58 (6.7), 57 (16), 43 (7.8), 41 (7.1). ${ }^{1} \mathrm{H}-\mathrm{NMR}\left(\mathrm{CDCl}_{3}\right): \delta 6.89(\mathrm{dd}, J=15.6$, $5.4 \mathrm{~Hz}, 1 \mathrm{H}, \mathrm{CHCH}=\mathrm{CH}), 6.12(\mathrm{dd}, J=15.6,1.6 \mathrm{~Hz}, 1 \mathrm{H}, \mathrm{O}=\mathrm{CCH}=\mathrm{CH}), 5.82($ broad s, $1 \mathrm{H}, \mathrm{NH}), 4.87$ (ddd, $J=6.7,5.4,1.6 \mathrm{~Hz}, 1 \mathrm{H}, \mathrm{H}-4), 4.85$ (d, $J=7.9 \mathrm{~Hz}, 1 \mathrm{H}, \mathrm{CHOAc}), 4.66$ (dd, $J=7.9,6.5 \mathrm{~Hz}, 1 \mathrm{H}, \mathrm{H}-5$ ), $4.19\left(\mathrm{q}, J=7.1 \mathrm{~Hz}, 2 \mathrm{H}, \mathrm{CH}_{2} \mathrm{CH}_{3}\right), 2.10\left(\mathrm{~s}, 3 \mathrm{H}, \mathrm{CH}_{3} \mathrm{CO}\right), 1.51,1.38\left(2 \mathrm{~s}, 2 \times 3 \mathrm{H}, \mathrm{C}\left(\mathrm{CH}_{3}\right)_{2}\right), 1.32(\mathrm{~s}, 9 \mathrm{H}$, $\left.\mathrm{C}\left(\mathrm{CH}_{3}\right)_{3}\right), 1.27\left(\mathrm{t}, J=7.1 \mathrm{~Hz}, 3 \mathrm{H}, \mathrm{CH}_{2} \mathrm{CH}_{3}\right) .{ }^{13} \mathrm{C}-\mathrm{NMR}\left(\mathrm{CDCl}_{3}\right): \delta 169.4,166.0,165.8(\mathrm{C}=\mathrm{O}), 141.3$ $(\mathrm{CHCH}=\mathrm{C}), 122.5(\mathrm{CHCH}=\mathrm{CH}), 109.6(\mathrm{C}-2), 76.4(\mathrm{C}-5), 76.1(\mathrm{C}-4), 71.3(\mathrm{CHOAc}), 60.6\left(\mathrm{CH}_{2} \mathrm{CH}_{3}\right), 51.7$

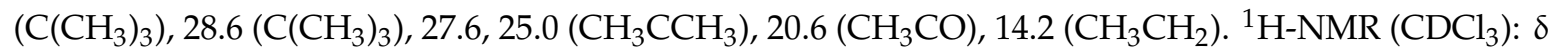
8.09-8.02 (m, $2 \mathrm{H}), 7.62(\mathrm{tt}, J=7.5,1.4 \mathrm{~Hz}, 1 \mathrm{H}), 7.53-7.44(\mathrm{~m}, 2 \mathrm{H}), 7.05-6.95(\mathrm{~m}, 1 \mathrm{H}, \mathrm{CH}=\mathrm{CHCO}), 6.16$ $(\mathrm{dd}, J=15.6,1.0 \mathrm{~Hz}, 1 \mathrm{H}, \mathrm{CH}=\mathrm{CHCO}), 5.90$ (broad s, $1 \mathrm{H}, \mathrm{NH}), 5.55-5.48(\mathrm{~m}, 1 \mathrm{H}, \mathrm{CHOBz}), 4.99-4.91$ (m, 2H, H-4, H-5), 4.16-4.04 (m, 2H, $\left.\mathrm{CH}_{2} \mathrm{CH}_{3}\right), 1.39$ (s, 6H, $\left.\left(\mathrm{CH}_{3}\right)_{2} \mathrm{C}\right), 1.34$ (s, 9H, C( $\left.\left.\mathrm{CH}_{3}\right)_{3}\right), 1.19$ $\left(\mathrm{t}, J=7.1 \mathrm{~Hz}, \mathrm{CH}_{3} \mathrm{CH}_{2}\right) \cdot{ }^{13} \mathrm{C}-\mathrm{NMR}\left(\mathrm{CDCl}_{3}\right): \delta 166.0,165.6,165.1(\mathrm{C}=\mathrm{O}), 142.2(\mathrm{CHCH}=\mathrm{C}), 133.7,129.9$ $(\times 2), 128.6(\times 2)$ (aromatic $\mathrm{CH}), 128.8$ (aromatic quat.), $123.0(\mathrm{CHCH}=\mathrm{CH}), 109.5(\mathrm{C}-2), 77.0$ (covered

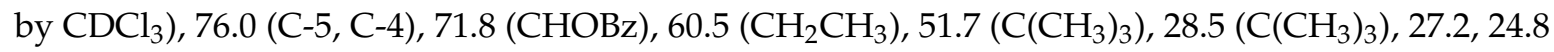
$\left(\mathrm{CH}_{3} \mathrm{CCH}_{3}\right), 14.1\left(\mathrm{CH}_{3} \mathrm{CH}_{2}\right)$. HRMS (ESI+): $m / z 456.1995\left(\mathrm{M}+\mathrm{Na}^{+}\right) . \mathrm{C}_{23} \mathrm{H}_{31} \mathrm{NNaO}_{7}$ requires: 456.1993.

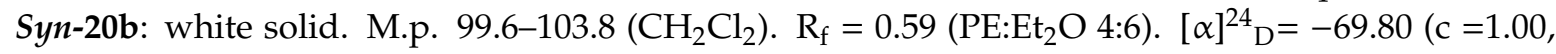
$\mathrm{CHCl}_{3}$ ). IR (ATR): $v_{\max } 3362,2981,2965,2937,1730,1713,1688,1603,1586,1543,1495,1454,1381,1364$, 1317, 1296, 1256, 1213, 1181, 1161, 1134, 1099, 1060, 1039, 987, 947, 914, 885, 851, 798, 765, 716, 688, 676, 633, 610. GC-MS: $\mathrm{R}_{\mathrm{t}} 12.23 \mathrm{~min}: \mathrm{m} / \mathrm{z} 418\left(\mathrm{M}^{+}-15,0.9\right), 171$ (9.4), 130 (5.9), 112 (8.8), 106 (8.8), 105 (100), 84 (12), 77 (15), 58 (6.6), 57 (14), 43 (6.2), 41 (5.3). ${ }^{1} \mathrm{H}-\mathrm{NMR}\left(\mathrm{CDCl}_{3}\right): \delta 8.14-8.04(\mathrm{~m}, 2 \mathrm{H}), 7.66-7.56$ $(\mathrm{m}, 1 \mathrm{H}), 7.53-7.43(\mathrm{~m}, 2 \mathrm{H}), 6.83(\mathrm{dd}, J=15.7,4.9 \mathrm{~Hz}, 1 \mathrm{H}, \mathrm{CH}=\mathrm{CHCO}), 6.06(\mathrm{dd}, J=15.6,1.4 \mathrm{~Hz}, 1 \mathrm{H}$, $\mathrm{CH}=\mathrm{CHCO}$ ), 5.96 (broad s, 1H, NH), $5.22(\mathrm{~d}, J=4.7 \mathrm{~Hz}, 1 \mathrm{H}, \mathrm{CHOBz}), 5.01-4.88(\mathrm{~m}, 2 \mathrm{H}, \mathrm{H}-4, \mathrm{H}-5), 4.03$ $\left(\mathrm{q}, J=7.1 \mathrm{~Hz}, 2 \mathrm{H}, \mathrm{CH}_{2} \mathrm{CH}_{3}\right), 1.59,1.42\left(2 \mathrm{~s}, 2 \times 3 \mathrm{H},\left(\mathrm{CH}_{3}\right)_{2} \mathrm{C}\right), 1.31\left(\mathrm{~s}, 9 \mathrm{H}, \mathrm{C}\left(\mathrm{CH}_{3}\right)_{3}\right), 1.14(\mathrm{t}, J=7.1 \mathrm{~Hz}$, $\left.\mathrm{CH}_{3} \mathrm{CH}_{2}\right) .{ }^{13} \mathrm{C}-\mathrm{NMR}\left(\mathrm{CDCl}_{3}\right): \delta 166.3,165.6,165.3(\mathrm{C}=\mathrm{O}), 141.6(\mathrm{CHCH}=\mathrm{C}), 133.7,129.9(\times 2), 128.6$ $(\times 2)$ (aromatic $\mathrm{CH}), 129.0$ (aromatic quat.), $123.4(\mathrm{CHCH}=\mathrm{CH}), 109.6(\mathrm{C}-2), 77.0$ (partially covered by $\left.\mathrm{CDCl}_{3}\right), 75.8(\mathrm{C}-5, \mathrm{C}-4), 73.3(\mathrm{CHOBz}), 60.4\left(\mathrm{CH}_{2} \mathrm{CH}_{3}\right), 51.6\left(\mathrm{C}\left(\mathrm{CH}_{3}\right)_{3}\right), 28.5\left(\mathrm{C}\left(\mathrm{CH}_{3}\right)_{3}\right), 27.2,25.0$ $\left(\mathrm{CH}_{3} \mathrm{CCH}_{3}\right), 14.0\left(\mathrm{CH}_{3} \mathrm{CH}_{2}\right)$. HRMS (ESI+): $\mathrm{m} / z 456.1995\left(\mathrm{M}+\mathrm{Na}^{+}\right) . \mathrm{C}_{23} \mathrm{H}_{31} \mathrm{NNaO}_{7}$ requires: 456.1993.

Ethyl (E)-3-((4R,5R)-5-((R)-2-(tert-butylamino)-2-oxoethyl-1-(4-pentenoyloxy))-2,2-dimethyl-1,3-dioxolan-4-yl) acrylate (20c). It was prepared by method A in THF (overall yield anti + syn: $66 \%$ from ent-14, d.r. 47:53), and by method B (overall yield anti + syn: 53\% from ent-14, d.r. 78:22). Chromatography was performed with PE: $\mathrm{CH}_{2} \mathrm{Cl}_{2}: \mathrm{Et}_{2} \mathrm{O}$ 3:1:1. Anti-20c: colorless oil. $\mathrm{R}_{\mathrm{f}}=0.70$ (PE: $\mathrm{Et}_{2} \mathrm{O}$ 4:6). $\mathrm{R}_{\mathrm{f}}=0.25$ (PE/Et $\left.{ }_{2} \mathrm{O} 3: 7\right),[\alpha]^{24}{ }_{\mathrm{D}}=-22.22\left(\mathrm{c}=0.99, \mathrm{CHCl}_{3}\right) . \mathrm{IR}(\mathrm{ATR}): v_{\max } 3385,2987,2966,2940,1732,1714$, 1687, 1534, 1454, 1380, 1367, 1300, 1255, 1222, 1160, 1128, 1108, 1070, 1043, 1003, 984, 957, 931, 914, 881, 810, 790, 762, 744, 691, 666, 631, 603. GC-MS: $\mathrm{R}_{\mathrm{t}} 10.75 \mathrm{~min}: \mathrm{m} / \mathrm{z} 396\left(\mathrm{M}^{+}-15,0.1\right), 170(7.4), 154$ (6.1), 152 (5.4), 151 (5.9), 130 (11), 129 (5.8), 126 (7.4), 125 (10), 112 (25), 97 (15), 85 (7.9), 84 (40), 83 (58), 81 (8.8), 69 (5.3), 59 (13), 58 (33), 57 (51), 56 (8.9), 55 (100), 54 (6.6), 53 (7.1), 43 (25), 42 (6.2), 41 (27), 39 (15). ${ }^{1} \mathrm{H}-\mathrm{NMR}\left(\mathrm{CDCl}_{3}\right): \delta 6.90(\mathrm{dd}, J=15.6,5.6 \mathrm{~Hz}, 1 \mathrm{H}, \mathrm{CH}=\mathrm{CHCO}), 6.11(\mathrm{dd}, J=15.6,1.5 \mathrm{~Hz}, 1 \mathrm{H}$, 
$\mathrm{CH}=\mathrm{CHCO}), 5.81\left(\mathrm{ddt}, J=17.1,10.2,6.1 \mathrm{~Hz}, 1 \mathrm{H}, \mathrm{CH}=\mathrm{CH}_{2}\right), 5.79($ broad s, $1 \mathrm{H}, \mathrm{NH}), 5.13-4.98(\mathrm{~m}, 2 \mathrm{H}$, $\left.\mathrm{CH}=\mathrm{CH}_{2}\right), 5.03(\mathrm{~d}, J=7.2 \mathrm{~Hz}, 1 \mathrm{H}, \mathrm{CHOCO}), 4.87(\mathrm{ddd}, J=7.1,5.6,1.5 \mathrm{~Hz}, \mathrm{H}-4), 4.72(\mathrm{t}, J=7.1 \mathrm{~Hz}$, $\mathrm{H}-5), 4.20\left(\mathrm{q}, J=7.1 \mathrm{~Hz}, 2 \mathrm{H}, \mathrm{CH}_{2} \mathrm{CH}_{3}\right), 2.55-2.33\left(\mathrm{~m}, 2 \mathrm{H}, \mathrm{CH}_{2} \mathrm{CH}_{2}\right), 1.51,1.39\left(2 \mathrm{~s}, 2 \times 3 \mathrm{H},\left(\mathrm{CH}_{3}\right)_{2} \mathrm{C}\right)$, $1.32\left(\mathrm{~s}, 9 \mathrm{H}, \mathrm{C}\left(\mathrm{CH}_{3}\right)_{3}\right), 1.29\left(\mathrm{t}, J=7.1 \mathrm{~Hz}, \mathrm{CH}_{3} \mathrm{CH}_{2}\right) .{ }^{13} \mathrm{C}-\mathrm{NMR}\left(\mathrm{CDCl}_{3}\right): \delta 171.4,165.9,165.8(\mathrm{C}=\mathrm{O})$, $141.8(\mathrm{CHCH}=\mathrm{C}), 136.3\left(\mathrm{CH}=\mathrm{CH}_{2}\right), 122.6(\mathrm{CHCH}=\mathrm{CH}), 115.8\left(\mathrm{CH}=\mathrm{CH}_{2}\right), 109.5(\mathrm{C}-2), 76.5,76.0(\mathrm{C}-5$, C-4), $71.3(\mathrm{CHOCO}), 60.5\left(\mathrm{CH}_{2} \mathrm{CH}_{3}\right), 51.7\left(\mathrm{C}_{\left.\left(\mathrm{CH}_{3}\right)_{3}\right)}\right), 33.0,28.3\left(\mathrm{CH}_{2} \mathrm{CH}_{2} \mathrm{C}=\mathrm{C}\right), 28.5\left(\mathrm{C}\left(\mathrm{CH}_{3}\right)_{3}\right), 27.5$, $24.9\left(\mathrm{CH}_{3} \mathrm{CCH}_{3}\right), 14.2\left(\mathrm{CH}_{3} \mathrm{CH}_{2}\right)$. HRMS (ESI+): $\mathrm{m} / \mathrm{z} 434.2154\left(\mathrm{M}+\mathrm{Na}^{+}\right) . \mathrm{C}_{23} \mathrm{H}_{31} \mathrm{NNaO}_{7}$ requires:

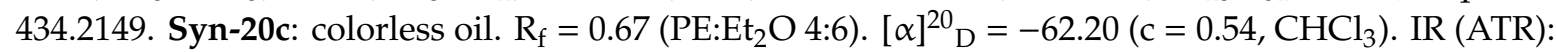
$v_{\max } 3376,2980,2936,1752,1720,1684,1524,1455,1367,1303,1254,1215,1160,1116,1060,1033,984$, 916, 883, 862, 796. GC-MS: $\mathrm{R}_{\mathrm{t}} 10.66 \mathrm{~min}: \mathrm{m} / \mathrm{z} 396\left(\mathrm{M}^{+}-15,0.8\right), 311$ (5.7), 254 (5.2), 198 (9.3), 197 (6.4), 181 (5.5), 172 (6.8), 171 (9.1), 170 (11), 154 (8.9), 153 (5.1), 152 (9.7), 151 (7.5), 143 (5.5), 131 (9.7), 130 (21), 129 (12), 126 (11), 125 (15), 113 (6.1), 112 (29), 108 (6.0), 101 (7.0), 97 (18), 85 (8.6), 84 (41), 83 (81), 82 (5.4), 81 (11), 69 (6.0), 59 (14), 58 (36), 57 (54), 56 (9.6), 55 (100), 54 (6.8), 53 (6.0), 43 (26), 42 (6.3), 41 (26), 39 (13). ${ }^{1} \mathrm{H}-\mathrm{NMR}\left(\mathrm{CDCl}_{3}\right): \delta 6.81(\mathrm{dd}, J=15.6,5.5 \mathrm{~Hz}, 1 \mathrm{H}, \mathrm{CH}=\mathrm{CHCO}), 6.09(\mathrm{dd}, J=15.6,1.6 \mathrm{~Hz}, 1 \mathrm{H}$, $\mathrm{CH}=\mathrm{CHCO}), 5.84($ broad s, $1 \mathrm{H}, \mathrm{NH}), 5.81\left(\mathrm{ddt}, J=17.1,10.2,6.1 \mathrm{~Hz}, 1 \mathrm{H}, \mathrm{CH}=\mathrm{CH}_{2}\right), 5.10(\mathrm{dq}, J=17.1$, $1.6 \mathrm{~Hz}, 1 \mathrm{H}, \mathrm{CHCHH}), 5.04(\mathrm{dq}, J=10.2,1.5 \mathrm{~Hz}, 1 \mathrm{H}, \mathrm{CHCHH}), 4.95(\mathrm{~d}, J=5.8 \mathrm{~Hz}, 1 \mathrm{H}, \mathrm{CHOCO}), 4.89$ (ddd, $J=7.1,5.6,1.6 \mathrm{~Hz}, \mathrm{H}-4), 4.75(\mathrm{dd}, J=7.0,5.8 \mathrm{~Hz}, \mathrm{H}-5), 4.19\left(\mathrm{q}, J=7.2 \mathrm{~Hz}, 2 \mathrm{H}, \mathrm{CH}_{2} \mathrm{CH}_{3}\right), 2.55-2.35$ $\left(\mathrm{m}, 2 \mathrm{H}, \mathrm{CH}_{2} \mathrm{CH}_{2}\right), 1.52,1.38\left(2 \mathrm{~s}, 2 \times 3 \mathrm{H},\left(\mathrm{CH}_{3}\right)_{2} \mathrm{C}\right), 1.31\left(\mathrm{~s}, 9 \mathrm{H}, \mathrm{C}\left(\mathrm{CH}_{3}\right)_{3}\right), 1.28\left(\mathrm{t}, J=7.2 \mathrm{~Hz}, \mathrm{CH}_{3} \mathrm{CH}_{2}\right)$. ${ }^{13} \mathrm{C}-\mathrm{NMR}\left(\mathrm{CDCl}_{3}\right): \delta 172.2,166.2,165.6(\mathrm{C}=\mathrm{O}), 141.9(\mathrm{CHCH}=\mathrm{C}), 136.2\left(\mathrm{CH}=\mathrm{CH}_{2}\right), 123.5(\mathrm{CHCH}=\mathrm{CH})$, $116.0\left(\mathrm{CH}=\mathrm{CH}_{2}\right), 109.7(\mathrm{C}-2), 76.7,75.9(\mathrm{C}-5, \mathrm{C}-4), 72.8(\mathrm{CHOCO}), 60.6\left(\mathrm{CH}_{2} \mathrm{CH}_{3}\right), 51.6\left(\mathrm{C}_{\left.\left(\mathrm{CH}_{3}\right)_{3}\right)}\right)$

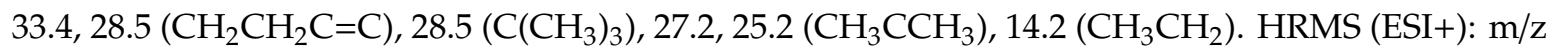
$434.2150\left(\mathrm{M}+\mathrm{Na}^{+}\right) \cdot \mathrm{C}_{23} \mathrm{H}_{31} \mathrm{NNaO}_{7}$ requires: 434.2149 .

Ethyl (E)-3-((4R,5R)-5-((R)-1-acetoxy-2-((2,6-dimethylphenyl)amino)-2-oxoethyl)-2,2-dimethyl-1,3-dioxolan-4-yl) acrylate (20d). It was prepared by method B in THF (overall yield anti + syn: 51\% from ent-14, d.r. 93:7). Chromatography was performed with $\mathrm{PE}: \mathrm{CH}_{2} \mathrm{Cl}_{2}: \mathrm{Et}_{2} \mathrm{O}$ 3:1:1. Anti-20d: white solid. M.p. 124.8-127.1 ${ }^{\circ} \mathrm{C}\left(\mathrm{CH}_{2} \mathrm{Cl}_{2}\right) . \mathrm{R}_{\mathrm{f}}=0.37\left(\mathrm{PE}: \mathrm{CH}_{2} \mathrm{Cl}_{2}: \mathrm{Et}_{2} \mathrm{O} 3: 2: 2\right) .[\alpha]^{20}{ }_{\mathrm{D}}=-48.78\left(\mathrm{c}=0.98, \mathrm{CHCl}_{3}\right) . \mathrm{IR}(\mathrm{ATR}): v_{\max } 3239$, 2985, 2928, 2855, 1747, 1717, 1660, 1540, 1472, 1371, 1304, 1259, 1227, 1161, 1120, 1069, 1041, 982, 928, 880, 800, 766, 708, 685. GC-MS: R $12.64 \mathrm{~min}: \mathrm{m} / \mathrm{z} 419\left(\mathrm{M}^{+}, 8.7\right), 419$ (8.7), 404 (8.3), 361 (11), 219 (30), 199 (5.8), 190 (6.3), 179 (6.7), 178 (15), 177 (100), 176 (33), 172 (5.7), 160 (7.7), 148 (47), 147 (12), 143 (6.1), 126 (15), 125 (6.0), 122 (6.7), 121 (27), 120 (13), 112 (12), 109 (6.2), 106 (5.8), 105 (11), 101 (6.7), 97 (18), 91 (5.0), 85 (9.1), 84 (20), 81 (5.0), 77 (6.6), 59 (8.2), 55 (6.6), 43 (66), 39 (5.6). ${ }^{1} \mathrm{H}-\mathrm{NMR}\left(\mathrm{CDCl}_{3}\right): \delta 7.27$ (broad s, 1H, NH), 7.14-7.02 (m, 3H), $6.93(\mathrm{dd}, J=15.6,5.1 \mathrm{~Hz}, 1 \mathrm{H}, \mathrm{CHCH}=\mathrm{CH}), 6.19(\mathrm{dd}, J=15.6$, $1.2 \mathrm{~Hz}, 1 \mathrm{H}, \mathrm{O}=\mathrm{CCH}=\mathrm{CH}), 4.96(\mathrm{ddd}, J=6.3,5.1,1.2 \mathrm{~Hz}, 1 \mathrm{H}, \mathrm{H}-4), 4.87(\mathrm{~d}, J=9.6 \mathrm{~Hz}, 1 \mathrm{H}, \mathrm{CHOAc})$, $4.70(\mathrm{dd}, J=9.6,6.3 \mathrm{~Hz}, 1 \mathrm{H}, \mathrm{H}-5), 4.19\left(\mathrm{q}, J=7.2 \mathrm{~Hz}, 2 \mathrm{H}, \mathrm{C}_{2} \mathrm{CH}_{3}\right), 2.21\left(\mathrm{~s}, 6 \mathrm{H}, \mathrm{CH}_{3} \mathrm{Ar}\right), 2.13(\mathrm{~s}, 3 \mathrm{H}$, $\left.\mathrm{CH}_{3} \mathrm{CO}\right), 1.59,1.43\left(2 \mathrm{~s}, 2 \times 3 \mathrm{H}, \mathrm{C}\left(\mathrm{CH}_{3}\right)_{2}\right), 1.29\left(\mathrm{t}, J=7.2 \mathrm{~Hz}, 3 \mathrm{H}, \mathrm{CH}_{2} \mathrm{CH}_{3}\right) .{ }^{13} \mathrm{C}-\mathrm{NMR}\left(\mathrm{CDCl}_{3}\right): \delta 169.6$, 165.7, $165.5(\mathrm{C}=\mathrm{O}), 140.8(\mathrm{CHCH}=\mathrm{C}), 135.4(\times 2), 133.0$ (aromatic quat.), $128.1(\times 2), 127.4$ (aromatic $\mathrm{CH}), 122.5(\mathrm{CHCH}=\mathrm{CH}), 110.1(\mathrm{C}-2), 76.2(\mathrm{C}-4), 75.9(\mathrm{C}-5), 71.2(\mathrm{CHOAc}), 60.6\left(\mathrm{CH}_{2} \mathrm{CH}_{3}\right), 27.8,25.1$ $\left(\mathrm{CH}_{3} \mathrm{CCH}_{3}\right), 20.3\left(\mathrm{CH}_{3} \mathrm{CO}\right), 18.3\left(\mathrm{CH}_{3} \mathrm{Ar}\right), 14.2\left(\mathrm{CH}_{3} \mathrm{CH}_{2}\right)$. HRMS (ESI+): $\mathrm{m} / \mathrm{z} 442.1846\left(\mathrm{M}+\mathrm{Na}^{+}\right)$. $\mathrm{CH}_{29} \mathrm{NNaO}_{7}$ requires: 442.1836 .

Ethyl (E)-3-((4R,5R)-5-((R)-1-acetoxy-2-(1,1-bis-(ethoxycarbonyl)-3-butenylamino)-2-oxoethyl)-2,2-dimethyl-1, 3-dioxolan-4-yl)acrylate (20e). It was prepared by method B in THF (overall yield anti + syn: $64 \%$ from ent-14, d.r. 98:2). Chromatography was performed with $\mathrm{PE}: \mathrm{CH}_{2} \mathrm{Cl}_{2}: \mathrm{Et}_{2} \mathrm{O}$ 3:1:1. Anti-20e: pale yellow oil. $\mathrm{R}_{\mathrm{f}}=0.45$ (PE: $\left.\mathrm{CH}_{2} \mathrm{Cl}_{2}: \mathrm{Et}_{2} \mathrm{O} 3: 1: 1\right) .[\alpha]^{20}{ }_{\mathrm{D}}=-39.19\left(\mathrm{c}=1.04, \mathrm{CHCl}_{3}\right) . \mathrm{IR}(\mathrm{ATR}): \gamma_{\max } 3410,2984,2925$, 2855, 1740, 1720, 1695, 1505, 1466, 1370, 1305, 1259, 1213, 1178, 1160, 1096, 1060, 1014, 987, 928, 882, 857, 795, 756, 665. GC-MS: $\mathrm{R}_{\mathrm{t}} 12.29 \mathrm{~min}: \mathrm{m} / \mathrm{z} 498\left(\mathrm{M}^{+}-15,11\right), 498$ (11), 455 (9.6), 440 (11), 410 (5.8), 396 (5.9), 383 (6.7), 382 (35), 344 (15), 313 (7.5), 272 (5.5), 271 (19), 241 (10), 239 (8.9), 229 (7.7), 216 (7.5), 214 (10), 213 (6.3), 199 (34), 198 (13), 181 (12), 174 (13), 172 (6.0), 171 (25), 170 (27), 168 (7.1), 153 (12), 143 (20), 142 (51), 141 (9.1), 126 (7.3), 125 (17), 124 (10), 114 (5.4), 113 (8.5), 112 (58), 111 (6.0), 109 (6.6), 101 (14), 97 (37), 96 (16), 87 (6.7), 85 (17), 84 (41), 83 (7.1), 81 (7.5), 73 (5.2), 71 (5.8), 69 (11), 68 (26), 59 (12), 55 
(9.4), 44 (8.6), 43 (100), 41 (14), 39 (6.9). ${ }^{1} \mathrm{H}-\mathrm{NMR}\left(\mathrm{CDCl}_{3}\right)$ : $\delta 7.44$ (broad s, $\left.1 \mathrm{H}, \mathrm{NH}\right), 6.89(\mathrm{dd}, J=15.6$, $4.9 \mathrm{~Hz}, 1 \mathrm{H}, \mathrm{CH}=\mathrm{CHCO}), 6.15(\mathrm{dd}, J=15.6,1.4 \mathrm{~Hz}, 1 \mathrm{H}, \mathrm{CH}=\mathrm{CHCO}), 5.58(\mathrm{ddt}, J=17.8,10.2,7.4 \mathrm{~Hz}$, $\left.1 \mathrm{H}, \mathrm{CH}=\mathrm{CH}_{2}\right), 5.17-5.05\left(\mathrm{~m}, 2 \mathrm{H}, \mathrm{CH}=\mathrm{CH}_{2}\right), 4.29-4.14\left(\mathrm{~m}, 6 \mathrm{H}, \mathrm{CH}_{2} \mathrm{CH}_{3}\right), 3,07,3.03(\mathrm{AB}$ part of an $\mathrm{ABX}$ syst., $\left.\mathrm{J}_{\mathrm{AB}}=14.2 \mathrm{~Hz}, \mathrm{~J}_{\mathrm{AX}}=7.9 \mathrm{~Hz}, \mathrm{~J}_{\mathrm{BX}}=7.1 \mathrm{~Hz}, 2 \mathrm{H}, \mathrm{CH}_{2} \mathrm{CH}=\mathrm{CH}_{2}\right), 2.09\left(\mathrm{CH}_{3} \mathrm{CO}\right), 1.60,1.41(2 \mathrm{~s}, 2 \times 3 \mathrm{H}$, $\left.\left(\mathrm{CH}_{3}\right)_{2} \mathrm{C}\right), 1.28\left(\mathrm{t}, J=7.2 \mathrm{~Hz}, \mathrm{CH}_{3} \mathrm{CH}_{2}\right), 1.25\left(\mathrm{t}, J=7.2 \mathrm{~Hz}, \mathrm{CH}_{3} \mathrm{CH}_{2}\right), 1.24\left(\mathrm{t}, J=7.2 \mathrm{~Hz}, \mathrm{CH}_{3} \mathrm{CH}_{2}\right)$. ${ }^{13} \mathrm{C}-\mathrm{NMR}\left(\mathrm{CDCl}_{3}\right): \delta 168.9,167.13,167.08,165.8,165.7(\mathrm{C}=\mathrm{O}), 140.5(\mathrm{CHCH}=\mathrm{C}), 131.0\left(\mathrm{CH}=\mathrm{CH}_{2}\right), 122.2$ $\left.(\mathrm{CHCH}=\mathrm{CH}), 119.9\left(\mathrm{CH}=\mathrm{CH}_{2}\right), 110.1(\mathrm{C}-2), 76.2(\mathrm{C}-4), 75.8(\mathrm{C}-5), 70.1(\mathrm{CHOAc}), 66.2\left(\mathrm{C}^{\left(\mathrm{CO}_{2} \mathrm{Et}\right)}\right)_{2}\right)$, $62.6(\times 2), 60.6\left(\mathrm{CH}_{2} \mathrm{CH}_{3}\right), 36.8\left(\mathrm{CH}_{2} \mathrm{CH}=\mathrm{CH}_{2}\right), 27.7,25.2\left(\mathrm{CH}_{3} \mathrm{CCH}_{3}\right), 20.3\left(\mathrm{CH}_{3} \mathrm{CO}\right), 14.2,13.9(\times 2)$ $\left(\mathrm{CH}_{3} \mathrm{CH}_{2}\right)$. HRMS (ESI+): $\mathrm{m} / \mathrm{z} 536.2091\left(\mathrm{M}+\mathrm{Na}^{+}\right) . \mathrm{C}_{24} \mathrm{H}_{35} \mathrm{NNaO}_{11}$ requires: 536.2102.

Ethyl (E)-3-((4R,5R)-5-((R)-1-benzoyloxy-2-((2,6-dimethylphenyl)amino)-2-oxoethyl)-2,2-dimethyl-1,3-dioxolan $-4-y l$ )acrylate (20f). It was prepared by method B in THF (overall yield ant $i+s y n: 57 \%$ from ent-14, d.r. 90:10). Chromatography was performed with $\mathrm{PE}: \mathrm{CH}_{2} \mathrm{Cl}_{2}: \mathrm{Et}_{2} \mathrm{O}$ 3:1:1. Anti-20f: white solid. M.p.

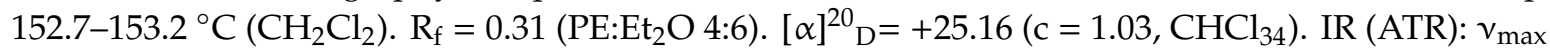
3247, 2987, 2935, 1726, 1671, 1602, 1515, 1475, 1452, 1371, 1263, 1223, 1176, 1161, 1110, 1071, 1030, 983, 880, 864, 766, 708, 682, 654, 619. ${ }^{1} \mathrm{H}-\mathrm{NMR}\left(\mathrm{CDCl}_{3}\right): \delta 8.08-8.02(\mathrm{~m}, 2 \mathrm{H}), 7.60(\mathrm{tt}, J=7.5,1.4 \mathrm{~Hz}, 1 \mathrm{H}), 7.46$ $(\mathrm{t}, J=7.5 \mathrm{~Hz}, 2 \mathrm{H}), 7.37$ (broad s, $1 \mathrm{H}, \mathrm{NH}), 7.14-7.02(\mathrm{~m}, 3 \mathrm{H}), 6.96(\mathrm{dd}, J=15.6,5.4 \mathrm{~Hz}, 1 \mathrm{H}, \mathrm{CHCH}=\mathrm{CH})$, $6.16(\mathrm{dd}, J=15.6,1.6 \mathrm{~Hz}, 1 \mathrm{H}, \mathrm{O}=\mathrm{CCH}=\mathrm{CH}), 5.36(\mathrm{~d}, J=8.5 \mathrm{~Hz}, 1 \mathrm{H}, \mathrm{CHOBz}), 5.03(\mathrm{ddd}, J=6.4,5.4$, $1.5 \mathrm{~Hz}, 1 \mathrm{H}, \mathrm{H}-4), 4.94(\mathrm{dd}, J=8.5,6.4 \mathrm{~Hz}, 1 \mathrm{H}, \mathrm{H}-5), 3.99,3.96$ (AB part of an $\mathrm{ABX}_{3}$ syst., $\mathrm{J}_{\mathrm{AB}}=11.0 \mathrm{~Hz}$, $\left.\mathrm{J}_{\mathrm{AX}}=\mathrm{J}_{\mathrm{BX}}=7.2 \mathrm{~Hz}, 2 \mathrm{H}, \mathrm{CH}_{2} \mathrm{CH}_{3}\right), 2.23\left(\mathrm{~s}, 6 \mathrm{H}, \mathrm{CH}_{3} \mathrm{Ar}\right), 1.58,1.46\left(2 \mathrm{~s}, 2 \times 3 \mathrm{H}, \mathrm{C}\left(\mathrm{CH}_{3}\right)_{2}\right), 1.08(\mathrm{t}, J=7.2$ $\left.\mathrm{Hz}, 3 \mathrm{H}, \mathrm{CH}_{2} \mathrm{CH}_{3}\right) .{ }^{13} \mathrm{C}-\mathrm{NMR}\left(\mathrm{CDCl}_{3}\right): \delta 165.4(\times 2), 165.3(\mathrm{C}=\mathrm{O}), 141.2(\mathrm{CHCH}=\mathrm{C}), 135.4(\times 2), 133.0$, 128.6 (aromatic quat.), $133.7(\times 2), 130.0(\times 2), 128.5,128.2(\times 2), 127.5$ (aromatic $\mathrm{CH}), 123.3(\mathrm{CHCH}=\mathrm{CH})$, 110.2 (C-2), $76.4(\mathrm{C}-4, \mathrm{C}-5), 71.7(\mathrm{CHOBz}), 60.4\left(\mathrm{CH}_{2} \mathrm{CH}_{3}\right), 27.8,25.2\left(\mathrm{CH}_{3} \mathrm{CCH}_{3}\right), 18.4\left(\mathrm{CH}_{3} \mathrm{Ar}\right), 14.0$ $\left(\mathrm{CH}_{3} \mathrm{CH}_{2}\right)$. HRMS (ESI+): $\mathrm{m} / \mathrm{z} 504.2008\left(\mathrm{M}+\mathrm{Na}^{+}\right) . \mathrm{C}_{27} \mathrm{H}_{31} \mathrm{NNaO}_{7}$ requires: 504.1993.

Ethyl (E)-3-((4R,5R)-5-((R)-1-benzoyloxy-2-(2-(4-benzyloxyphenyl)ethylamino)-2-oxoethyl)-2,2-dimethyl-1,3dioxolan-4-yl)acrylate (20g). It was prepared by method B in THF (overall yield anti + syn: $63 \%$ from ent-14, d.r. 85:15). Chromatography was performed with $\mathrm{PE}: \mathrm{CH}_{2} \mathrm{Cl}_{2}: \mathrm{Et}_{2} \mathrm{O}$ 3:1:1. Anti-20g: pale yellow solid. M.p. $119.5-122.3{ }^{\circ} \mathrm{C}\left(\mathrm{CH}_{2} \mathrm{Cl}_{2}\right)$. $\mathrm{R}_{\mathrm{f}}=0.64\left(\mathrm{PE}_{\mathrm{Et}} \mathrm{O} 4: 6\right) . \quad[\alpha]^{24}{ }_{\mathrm{D}}=-43.85\left(\mathrm{c}=1.00, \mathrm{CHCl}_{3}\right)$. IR (ATR): $v_{\max } 3409,2983,2937,1714,1683,1611,1583,1530,1511,1453,1379,1241,1177,1162$, 1111, 1070, 1026, 991, 878, 858, 806, 736, 711, 695. ${ }^{1} \mathrm{H}-\mathrm{NMR}\left(\mathrm{CDCl}_{3}\right): \delta 8.02(\mathrm{~d}, J=8.2 \mathrm{~Hz}, 2 \mathrm{H}), 7.60$ $(\mathrm{t}, J=7.3 \mathrm{~Hz}, 1 \mathrm{H}), 7.46(\mathrm{t}, J=7.8 \mathrm{~Hz}, 2 \mathrm{H}), 7.43-7.28(\mathrm{~m}, 5 \mathrm{H}), 7.04(\mathrm{~d}, J=8.2 \mathrm{~Hz}, 2 \mathrm{H}), 6.96(\mathrm{dd}, J=15.6$, $5.4 \mathrm{~Hz}, 1 \mathrm{H}, \mathrm{CHCH}=\mathrm{CH}), 6.76(\mathrm{~d}, J=8.2 \mathrm{~Hz}, 2 \mathrm{H}), 6.16(\mathrm{t}, J=6.0 \mathrm{~Hz}, 1 \mathrm{H}, \mathrm{NH}), 6.12(\mathrm{~d}, J=15.6 \mathrm{~Hz}$, $1 \mathrm{H}, \mathrm{O}=\mathrm{CCH}=\mathrm{CH}), 5.49(\mathrm{~d}, J=5.2 \mathrm{~Hz}, 1 \mathrm{H}, \mathrm{CHOBz}), 4.93\left(\mathrm{~s}, 4 \mathrm{H}, \mathrm{CH}_{2} \mathrm{Ph}, \mathrm{H}-4, \mathrm{H}-5\right), 4.04,4.01$ (AB part of an $\mathrm{ABX}_{3}$ syst., $\left.\mathrm{J}_{\mathrm{AB}}=11.0 \mathrm{~Hz}, \mathrm{~J}_{\mathrm{AX}}=\mathrm{J}_{\mathrm{BX}}=7.2 \mathrm{~Hz}, 2 \mathrm{H}, \mathrm{CH}_{2} \mathrm{CH}_{3}\right), 3.58-3.36\left(\mathrm{~m}, 2 \mathrm{H}, \mathrm{NHCH}_{2}\right), 2.72$ $\left(\mathrm{t}, J=6.9 \mathrm{~Hz}, 2 \mathrm{H}, \mathrm{NHCH}_{2} \mathrm{CH}_{2}\right), 1.37\left(\mathrm{~s}, 6 \mathrm{H}, \mathrm{C}\left(\mathrm{CH}_{3}\right)_{2}\right), 1.13\left(\mathrm{t}, J=7.1 \mathrm{~Hz}, 3 \mathrm{H}, \mathrm{CH}_{2} \mathrm{CH}_{3}\right) .{ }^{13} \mathrm{C}-\mathrm{NMR}$ $\left(\mathrm{CDCl}_{3}\right): \delta 166.7,165.5,164.9(\mathrm{C}=\mathrm{O}), 157.4,137.0,130.6,128.6$ (aromatic quat.), $141.9(\mathrm{CHCH}=\mathrm{C})$, 133.7, $129.9(\times 2), 129.6(\times 2), 128.54(\times 2), 128.51(\times 2), 127.9,127.3(\times 2), 114.9(\times 2)($ aromatic $\mathrm{CH}), 123.0$ $(\mathrm{CHCH}=\mathrm{CH}), 109.7(\mathrm{C}-2), 76.8,76.0(\mathrm{C}-4, \mathrm{C}-5), 71.5(\mathrm{CHOBz}), 69.8\left(\mathrm{PhCH}_{2} \mathrm{O}\right), 60.4\left(\mathrm{CH}_{2} \mathrm{CH}_{3}\right), 40.5$ $\left(\mathrm{NHCH}_{2}\right), 34.3\left(\mathrm{NHCH}_{2} \mathrm{CH}_{2}\right), 27.2,24.8\left(\mathrm{CH}_{3} \mathrm{CCH}_{3}\right), 14.0\left(\mathrm{CH}_{3} \mathrm{CH}_{2}\right)$. HRMS (ESI+): m/z 610,2427 $\left(\mathrm{M}+\mathrm{Na}^{+}\right) \cdot \mathrm{C}_{34} \mathrm{H}_{37} \mathrm{NNaO}_{8}$ requires: 610.2411.

Ethyl (E)-3-((4R,5R)-5-(2-benzylamino-(R)-1-((2-methylbenzoyl)oxy)-2-oxoethyl)-2,2-dimethyl-1,3-dioxolan-4-yl) acrylate (20h). It was prepared by method B in THF (overall yield anti + syn: 56\% from ent-14, d.r. 88:12). Chromatography was performed with PE: $\mathrm{CH}_{2} \mathrm{Cl}_{2}: \mathrm{Et}_{2} \mathrm{O}$ 3:1:1. Anti-20h: white solid. M.p. 83.8-85.9 ${ }^{\circ} \mathrm{C}$ $\left(\mathrm{CH}_{2} \mathrm{Cl}_{2}\right) . \mathrm{R}_{\mathrm{f}}=0.64\left(\mathrm{PE}: \mathrm{Et}_{2} \mathrm{O} 4: 6\right) .[\alpha]^{24}{ }_{\mathrm{D}}=-33.33\left(\mathrm{c}=1.01, \mathrm{CHCl}_{3}\right) . \mathrm{IR}(\mathrm{ATR}): v_{\max } 3331,2984,2931$, 1723, 1664, 1601, 1551, 1494, 1455, 1434, 1387, 1367, 1307, 1235, 1208, 1173, 1157, 1141, 1071, 1029, 972, 922, 880, 858, 802, 737, 696, 668, 639. ${ }^{1} \mathrm{H}-\mathrm{NMR}\left(\mathrm{CDCl}_{3}\right): \delta 7.96(\mathrm{dd}, J=8.1,1.5 \mathrm{~Hz}, 1 \mathrm{H}), 7.43(\mathrm{td}, J=7.5$, $1.2 \mathrm{~Hz}, 1 \mathrm{H}), 7.35-7.21(\mathrm{~m}, 7 \mathrm{H}), 6.93(\mathrm{dd}, J=15.6,5.4 \mathrm{~Hz}, 1 \mathrm{H}, \mathrm{CHCH}=\mathrm{CH}), 6.46(\mathrm{t}, J=6.0 \mathrm{~Hz}, 1 \mathrm{H}$, $\mathrm{NH}), 6.12(\mathrm{dd}, J=15.6,1.3 \mathrm{~Hz}, 1 \mathrm{H}, \mathrm{O}=\mathrm{CCH}=\mathrm{CH}), 5.38(\mathrm{~d}, J=7.0 \mathrm{~Hz}, 1 \mathrm{H}, \mathrm{CHOCO}), 4.98-4.87(\mathrm{~m}, 2 \mathrm{H}$, $\mathrm{H}-4, \mathrm{H}-5), 4.61$ (dd, J = 15.1, $6.5 \mathrm{~Hz}, 1 \mathrm{H}, \mathrm{CHHPh}), 4.33$ (dd, $J=15.1,5.1 \mathrm{~Hz}, 1 \mathrm{H}, \mathrm{CHHPh}), 4.05,4.02$ $\left(\mathrm{AB}\right.$ part of an $\mathrm{ABX}_{3}$ syst., $\left.\mathrm{J}_{\mathrm{AB}}=11.0 \mathrm{~Hz}, \mathrm{~J}_{\mathrm{AX}}=\mathrm{J}_{\mathrm{BX}}=7.1 \mathrm{~Hz}, 2 \mathrm{H}, \mathrm{CH}_{2} \mathrm{CH}_{3}\right), 2.57\left(\mathrm{~s}, 3 \mathrm{H}, \mathrm{CH}_{3} \mathrm{Ar}\right), 1.46$, 
$1.41\left(2 \mathrm{~s}, 2 \times 3 \mathrm{H}, \mathrm{C}\left(\mathrm{CH}_{3}\right)_{2}\right), 1.13\left(\mathrm{t}, J=7.1 \mathrm{~Hz}, 3 \mathrm{H}, \mathrm{CH}_{2} \mathrm{CH}_{3}\right) .{ }^{13} \mathrm{C}-\mathrm{NMR}\left(\mathrm{CDCl}_{3}\right): \delta 167.2,165.41,165.38$ $(\mathrm{C}=\mathrm{O}), 141.5(\mathrm{CHCH}=\mathrm{C}), 141.3,137.5,127.6$ (aromatic quat.), 132.7, 131.8, 130.8, $128.6(\times 2), 127.5(\times 2)$, 127.4, 125.8 (aromatic $\mathrm{CH}), 123.2(\mathrm{CHCH}=\mathrm{CH}), 109.9(\mathrm{C}-2), 76.7,76.1(\mathrm{C}-4, \mathrm{C}-5), 71.3(\mathrm{CHOCO}), 60.4$ $\left(\mathrm{CH}_{2} \mathrm{CH}_{3}\right), 43.4\left(\mathrm{NHCH}_{2}\right), 27.3,24.9\left(\mathrm{CH}_{3} \mathrm{CCH}_{3}\right), 21.7\left(\mathrm{CH}_{3} \mathrm{Ar}\right), 14.0\left(\mathrm{CH}_{3} \mathrm{CH}_{2}\right)$. HRMS (ESI+): $\mathrm{m} / \mathrm{z}$ $504.1990\left(\mathrm{M}+\mathrm{Na}^{+}\right) \cdot \mathrm{C}_{27} \mathrm{H}_{31} \mathrm{NNaO}_{7}$ requires: 504.1993 .

Ethyl (E)-3-((4R,5R)-5-(2-cyclohexylamino-(R)-1-((2-methoxyacetoxy)-2-oxoethyl)-2,2-dimethyl-1,3-dioxolan-4 -yl)acrylate (20i). It was prepared by method B in THF (overall yield anti + syn: $64 \%$ from ent-14, d.r. 84:16). Chromatography was performed with $\mathrm{PE}: \mathrm{CH}_{2} \mathrm{Cl}_{2}: \mathrm{Et}_{2} \mathrm{O}$ 3:2:2. Anti-20i: white solid. M.p. 146.2-148.7 ${ }^{\circ} \mathrm{C}\left(\mathrm{CH}_{2} \mathrm{Cl}_{2}\right) . \mathrm{R}_{\mathrm{f}}=0.20\left(\mathrm{PE}: \mathrm{CH}_{2} \mathrm{Cl}_{2}: \mathrm{Et}_{2} \mathrm{O} 3: 2: 2\right) .[\alpha]^{24}{ }_{\mathrm{D}}=-43.13$ (c = 1.03, $\left.\mathrm{CHCl}_{3}\right)$. IR (ATR): $v_{\max } 3314,2989,2938,2856,1758,1716,1661,1550,1452,1420,1384,1356,1303,1259,1245,1225$, 1183, 1161, 1122, 1096, 1077, 1031, 978, 929, 889, 879, 853, 804, 760, 734, 720, 694, 665, 645. ${ }^{1} \mathrm{H}-\mathrm{NMR}$ $\left(\mathrm{CDCl}_{3}\right): \delta 6.87(\mathrm{dd}, J=15.6,5.4 \mathrm{~Hz}, 1 \mathrm{H}, \mathrm{CHCH}=\mathrm{CH}), 6.12(\mathrm{dd}, J=15.6,1.6 \mathrm{~Hz}, 1 \mathrm{H}, \mathrm{O}=\mathrm{CCH}=\mathrm{CH})$, $5.92(\mathrm{t}, J=8.4 \mathrm{~Hz}, 1 \mathrm{H}, \mathrm{NH}), 4.98(\mathrm{~d}, J=8.1 \mathrm{~Hz}, 1 \mathrm{H}, \mathrm{CHOCO}), 4.89(\mathrm{ddd}, J=6.6,5.4,1.6 \mathrm{~Hz}, \mathrm{H}-4), 4.69$ $(\mathrm{dd}, J=8.1,6.6 \mathrm{~Hz}, \mathrm{H}-5), 4.18\left(\mathrm{q}, J=7.1 \mathrm{~Hz}, 2 \mathrm{H}, \mathrm{CH}_{2} \mathrm{CH}_{3}\right), 4.13,4.07$ (AB syst., $J=16.8 \mathrm{~Hz}, \mathrm{CH}_{2} \mathrm{OMe}$ ), 3.84-3.69 (m, 1H, CHNH), $3.44\left(\mathrm{~s}, 3 \mathrm{H}, \mathrm{CH}_{3} \mathrm{O}\right), 1.94-1.82(\mathrm{~m}, 2 \mathrm{H}), 1.75-1.54(\mathrm{~m}, 4 \mathrm{H}), 1.52,1.39(2 \mathrm{~s}$, $\left.2 \times 3 \mathrm{H}, \mathrm{C}\left(\mathrm{CH}_{3}\right)_{2}\right), 1.40-1.27(\mathrm{~m}, 1 \mathrm{H}), 1.28\left(\mathrm{t}, J=7.2 \mathrm{~Hz}, 3 \mathrm{H}, \mathrm{CH}_{2} \mathrm{CH}_{3}\right), 1.25-1.05(\mathrm{~m}, 3 \mathrm{H}) .{ }^{13} \mathrm{C}-\mathrm{NMR}$ $\left(\mathrm{CDCl}_{3}\right): \delta 168.9,165.7,165.4(\mathrm{C}=\mathrm{O}), 141.0(\mathrm{CHCH}=\mathrm{C}), 122.6(\mathrm{CHCH}=\mathrm{CH}), 109.7(\mathrm{C}-2), 76.1,76.0$ (C-4, C-5), $71.0(\mathrm{CHOCO}), 69.3\left(\mathrm{CH}_{3} \mathrm{OCH}_{2}\right), 60.6\left(\mathrm{CH}_{2} \mathrm{CH}_{3}\right), 59.4\left(\mathrm{OCH}_{3}\right), 48.3(\mathrm{NHCH}), 32.7$, 32.5, 25.4, 24.5 ( $\times 2)\left(\mathrm{CH}_{2}\right.$ of cyclohexyl), 27.5, $24.9\left(\mathrm{CH}_{3} \mathrm{CCH}_{3}\right), 14.1\left(\mathrm{CH}_{3} \mathrm{CH}_{2}\right)$. HRMS (ESI+): $\mathrm{m} / \mathrm{z} 450.2101$ $\left(\mathrm{M}+\mathrm{Na}^{+}\right) . \mathrm{C}_{21} \mathrm{H}_{33} \mathrm{NNaO}_{8}$ requires: 450.2098 .

(R)-2-(tert-Butylamino)-1-((4R,5R)-5-((E)-3-(4-methoxyphenoxy)prop-1-en-1-yl)-2,2-dimethyl-1,3-dioxolan-4-yl) -2-oxoethyl pent-4-enoate (38). It was prepared by method A in THF (overall yield ant $i+$ syn: $74 \%$ from 37 , d.r. $62: 38$ ) and by method B (overall yield anti + syn: $45 \%$ from 37 , d.r. 77:23). Chromatography was

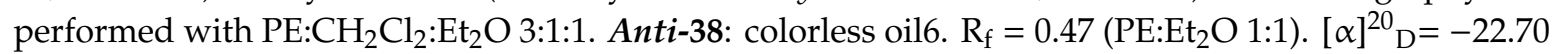
(c = 0.45, $\mathrm{CHCl}_{3}$ ). IR (ATR): $v_{\max } 3391,2977,2935,1745,1689,1507,1455,1367,1216,1163,1107,1063$, 1035, 973, 916, 877, 824, 798, 744, 711. GC-MS: $\mathrm{R}_{\mathrm{t}} 13.03 \mathrm{~min}: \mathrm{m} / \mathrm{z} 475\left(\mathrm{M}^{+}, 5.1\right), 475$ (5.1), 353 (21), 352 (100), 270 (13), 252 (11), 238 (5.8), 214 (14), 196 (9.2), 165 (5.1), 156 (7.9), 144 (8.8), 138 (14), 125 (8.1), 124 (54), 123 (20), 113 (5.5), 111 (33), 109 (11), 95 (13), 88 (11), 83 (31), 81 (7.1), 69 (8.9), 59 (7.9), 58 (17), 57 (32), 55 (54), 53 (13), 43 (13), 41 (15). ${ }^{1} \mathrm{H}-\mathrm{NMR}\left(\mathrm{CDCl}_{3}\right): \delta 6.82(\mathrm{~s}, 4 \mathrm{H}$, aromatic $\mathrm{H}), 6.02(\mathrm{dtd}, J=15.6$, $\left.4.8,0.6 \mathrm{~Hz}, 1 \mathrm{H}, \mathrm{CH}-\mathrm{CH}_{2} \mathrm{OPMP}\right), 5.91$ (ddt $\left.J=15.6,6.6,1.3 \mathrm{~Hz}, 1 \mathrm{H}, \mathrm{CH}=\mathrm{CHCH}_{2} \mathrm{OPMP}\right), 5.86(\mathrm{~s}, 1 \mathrm{H}$, $\mathrm{NH}), 5.77\left(\mathrm{ddt}, J=17.1,10.2,6.1 \mathrm{~Hz}, 1 \mathrm{H}, \mathrm{CH}=\mathrm{CH}_{2}\right), 5.06-4.95\left(\mathrm{~m}, 2 \mathrm{H}, \mathrm{CH}=\mathrm{CH}_{2}\right), 4.99(\mathrm{~d}, J=7.8 \mathrm{~Hz}$, $1 \mathrm{H}, \mathrm{CHOCO}), 4.77(\mathrm{t}, J=6.6 \mathrm{~Hz}, 1 \mathrm{H}, \mathrm{H}-5), 4.56(\mathrm{dd}, J=7.6,6.4 \mathrm{~Hz}, 1 \mathrm{H}, \mathrm{H}-4), 4.45(\mathrm{~d}, J=4.7 \mathrm{~Hz}, 2 \mathrm{H}$, $\left.\mathrm{CH}_{2} \mathrm{OPMP}\right), 3.77\left(\mathrm{OCH}_{3}\right), 2.56-2.30\left(\mathrm{~m}, 4 \mathrm{H}, \mathrm{CH}_{2} \mathrm{CH}_{2} \mathrm{CO}\right), 1.50,1.38\left(2 \mathrm{~s}, 2 \times 3 \mathrm{H},\left(\mathrm{CH}_{3}\right)_{2} \mathrm{C}\right), 1.33(\mathrm{~s}, 9 \mathrm{H}$, $\left.\left(\mathrm{CH}_{3}\right)_{3} \mathrm{C}\right) .{ }^{13} \mathrm{C}-\mathrm{NMR}\left(\mathrm{CDCl}_{3}\right): \delta 171.5,166.2(\mathrm{C}=\mathrm{O}), 154.0,152.6$ (aromatic quat.), $136.4\left(\mathrm{CH}=\mathrm{CH}_{2}\right)$, 129.3, 127.0 $(\mathrm{CH}=\mathrm{CH}), 115.8\left(\mathrm{CH}=\mathrm{CH}_{2}\right), 115.5,114.7$ (aromatic $\left.\mathrm{CH}\right), 109.1(\mathrm{C}-2), 77.5(\mathrm{C}-5), 76.4(\mathrm{C}-4)$,

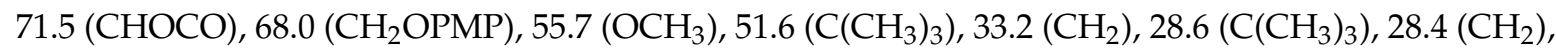
27.6, $25.1\left(\left(\mathrm{CH}_{3}\right)_{2} \mathrm{C}\right)$. HRMS (ESI+): $\mathrm{m} / \mathrm{z} 498,2443\left(\mathrm{M}+\mathrm{Na}^{+}\right) . \mathrm{C}_{26} \mathrm{H}_{37} \mathrm{NNaO}_{7}$ requires: 498,2462.

Ethyl 2-((3aR,4S,6R,6aR)-6-(tert-butylcarbamoyl)-2,2-dimethyltetrahydrofuro[3,4-d][1,3]dioxol-4-yl)acetate (24) and Ethyl 2-((3aR,4R,6R,6aR)-6-(tert-butylcarbamoyl)-2,2-dimethyltetrahydrofuro[3,4-d][1,3]dioxol-4-yl) acetate (25). A solution of sodium ethoxide $(1.6 \mathrm{~mL}, 0.1 \mathrm{M}$, prepared in situ by addition of sodium to $\mathrm{EtOH})$ was added to a solution of anti-20a $(100 \mathrm{mg}, 0,23 \mathrm{mmol})$ and the reaction was stirred at room temperature for $5 \mathrm{~h}$. The mixture was poured into saturated aq. $\mathrm{NH}_{4} \mathrm{Cl}(10 \mathrm{~mL})$ and extracted with $\mathrm{CH}_{2} \mathrm{Cl}_{2}$. The organic layers were washed with brine, dried, and concentrated. Chromatography with PE:Et ${ }_{2} \mathrm{O}$ afforded 24 (45 mg, 41\%) and a mixture of 24 and 25 (18 mg, 17\% yield), which was purified again to afford an analytical sample of 25 . The d.r. of the reaction is 90:10). The same reaction was performed under the same conditions starting from anti-20b and afforded the same product with an

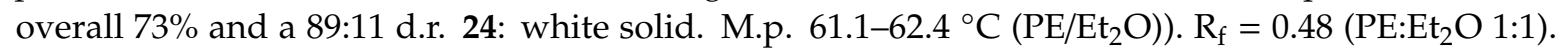
$[\alpha]^{21}{ }_{D}=-2.94\left(\mathrm{c}=1.00, \mathrm{CHCl}_{3}\right)$. IR (ATR): $v_{\max } 3389,2988,2964,2936,1729,1683,1524,1480,1457$, 1403, 1395, 1375, 1364, 1308, 1280, 1268, 1251, 1237, 1205, 1179, 1159, 1106, 1072, 1057, 1038, 1024, 992, 
973, 927, 897, 866, 839, 825, 809, 763, 698, 648, 616. GC-MS: $\mathrm{R}_{\mathrm{t}} 9.14 \mathrm{~min}: \mathrm{m} / \mathrm{z} 314\left(\mathrm{M}^{+}-15,0.8\right), 226(14)$, 186 (18), 185 (12), 184 (100), 172 (17), 171 (30), 170 (16), 155 (20), 154 (5.4), 143 (8.5), 129 (9.3), 128 (26), 127 (14), 126 (27), 125 (11), 109 (5.1), 101 (27), 100 (6.3), 99 (11), 98 (14), 97 (18), 88 (18), 87 (30), 85 (41), 84 (17), 83 (7.8), 82 (7.0), 81 (37), 74 (7.0), 73 (7.7), 71 (11), 70 (8.2), 69 (8.6), 59 (18), 58 (33), 57 (79), 56 (7.1), 55 (15), 43 (39), 42 (9.0), 41 (32), 39 (7.0). ${ }^{1} \mathrm{H}-\mathrm{NMR}\left(\mathrm{CDCl}_{3}\right): \delta 6.72(\mathrm{~s}, 1 \mathrm{H}, \mathrm{NH}), 5.18(\mathrm{dd}, J=6.0$, $0.3 \mathrm{~Hz}, 1 \mathrm{H}, \mathrm{H}-6 \mathrm{a}), 4.63$ (dd, J = 6.0, $3.6 \mathrm{~Hz}, 1 \mathrm{H}, \mathrm{H}-3 \mathrm{a}$ ), 4.32 (s, 1H, H-6), 4.21, 4.18 (AB part of an $\mathrm{ABX}_{3}$ syst., $\left.\mathrm{J}_{\mathrm{AB}}=10.5 \mathrm{~Hz}, \mathrm{~J}_{\mathrm{AX}}=\mathrm{J}_{\mathrm{BX}}=7.2 \mathrm{~Hz}, 2 \mathrm{H}, \mathrm{CH}_{2} \mathrm{CH}_{3}\right), 4.08(\mathrm{dtd}, J=9.0,3.8,0.3 \mathrm{~Hz}, 1 \mathrm{H}, \mathrm{H}-4), 2.81,2.70$ ( $\mathrm{AB}$ part of an $\mathrm{ABX}$ syst., $\left.\mathrm{J}_{\mathrm{AB}}=17.4 \mathrm{~Hz}, \mathrm{~J}_{\mathrm{AX}}=3.8 \mathrm{~Hz}, \mathrm{~J}_{\mathrm{BX}}=9.0 \mathrm{~Hz} ., 2 \mathrm{H}, \mathrm{CH}_{2} \mathrm{CO}_{2} \mathrm{Et}\right), 1.47,1.32(2 \mathrm{~s}$, $\left.2 \times 3 \mathrm{H}, \mathrm{C}\left(\mathrm{CH}_{3}\right)_{2}\right), 1.37\left(\mathrm{~s}, 9 \mathrm{H}, \mathrm{C}\left(\mathrm{CH}_{3}\right)_{3}\right), 1.29\left(\mathrm{t}, J=7.2 \mathrm{~Hz}, 3 \mathrm{H}, \mathrm{CH}_{2} \mathrm{CH}_{3}\right) .{ }^{13} \mathrm{C}-\mathrm{NMR}\left(\mathrm{CDCl}_{3}\right): \delta 171.1$,

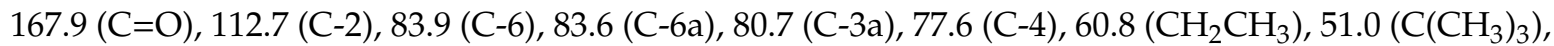

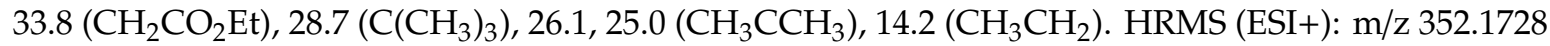

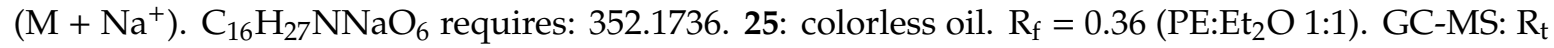
$9.40 \mathrm{~min}: \mathrm{m} / \mathrm{z} 314$ (M+15, 0.7), 271 (16), 254 (6.3), 229 (17), 215 (32), 198 (7.7), 184 (16), 173 (5.2), 172 (46), 171 (21), 170 (9.3), 155 (11), 152 (13), 143 (11), 135 (5.4), 129 (7.2), 128 (6.4), 127 (14), 126 (19), 125 (14), 109 (9.9), 101 (18), 100 (6.0), 99 (8.8), 98 (10), 97 (32), 88 (33), 86 (6.7), 85 (100), 84 (17), 83 (7.7), 81 (18), 74 (6.5), 73 (7.8), 71 (12), 70 (9.9), 69 (10), 61 (6.8), 60 (6.2), 59 (24), 58 (35), 57 (82), 56 (8.3), 55 (15), 43 (52), $42(13), 41(40), 39(9.5) .{ }^{1} \mathrm{H}-\mathrm{NMR}\left(\mathrm{CDCl}_{3}\right): \delta 6.57(\mathrm{~s}, 1 \mathrm{H}, \mathrm{NH}), 4.94(\mathrm{dd}, J=6.4,2.8 \mathrm{~Hz}, 1 \mathrm{H}$, $\mathrm{H}-6 \mathrm{a}), 4.52(\mathrm{dd}, J=6.4,3.8 \mathrm{~Hz}, 1 \mathrm{H}, \mathrm{H}-3 \mathrm{a}), 4.22(\mathrm{dt}, J=8.2,4.1 \mathrm{~Hz}, 1 \mathrm{H}, \mathrm{H}-4), 4.36(\mathrm{~d}, J=2.8 \mathrm{~Hz}, 1 \mathrm{H}$, $\mathrm{H}-6), 4.19\left(\mathrm{q}, J=7.2 \mathrm{~Hz}, 2 \mathrm{H}, \mathrm{CH}_{2} \mathrm{CH}_{3}\right), 2.66,2.54$ (AB part of an $\mathrm{ABX}$ syst., $\mathrm{J}_{\mathrm{AB}}=15.5 \mathrm{~Hz}, \mathrm{~J}_{\mathrm{AX}}=8.1 \mathrm{~Hz}$, $\left.\mathrm{J}_{\mathrm{BX}}=4.5 \mathrm{~Hz}, 2 \mathrm{H}, \mathrm{CH}_{2} \mathrm{CO}_{2} \mathrm{Et}\right), 1.54,1.34\left(2 \mathrm{~s}, 2 \times 3 \mathrm{H}, \mathrm{C}\left(\mathrm{CH}_{3}\right)_{2}\right), 1.36\left(\mathrm{~s}, 9 \mathrm{H}, \mathrm{C}\left(\mathrm{CH}_{3}\right)_{3}\right), 1.29(\mathrm{t}, J=7.2 \mathrm{~Hz}$, $\left.3 \mathrm{H}, \mathrm{CH}_{2} \mathrm{CH}_{3}\right) .{ }^{13} \mathrm{C}-\mathrm{NMR}\left(\mathrm{CDCl}_{3}\right): \delta 170.2,169.1(\mathrm{C}=\mathrm{O}), 114.1(\mathrm{C}-2), 84.5(\mathrm{C}-6), 83.8(\mathrm{C}-6 \mathrm{a}), 83.4(\mathrm{C}-3 \mathrm{a})$,

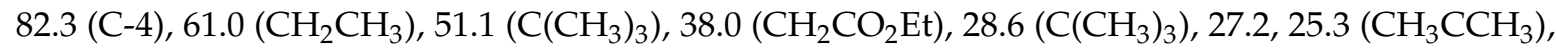
14.2 $\left(\mathrm{CH}_{3} \mathrm{CH}_{2}\right)$. HRMS (ESI+): $\mathrm{m} / \mathrm{z} 352.1728\left(\mathrm{M}+\mathrm{Na}^{+}\right) \cdot \mathrm{C}_{16} \mathrm{H}_{27} \mathrm{NNaO}_{6}$ requires: 352.1730.

Ethyl 2-((3aR,4S,6S,6aR)-6-(tert-butylcarbamoyl)-2,2-dimethyltetrahydrofuro[3,4-d][1,3]dioxol-4-yl)acetate (26) and Ethyl 2-((3aR,4R,6S,6aR)-6-(tert-butylcarbamoyl)-2,2-dimethyltetrahydrofuro[3,4-d][1,3]dioxol-4-yl) acetate (27). Compounds $\mathbf{2 6}$ and $\mathbf{2 7}$ were obtained under the same conditions described for compounds 24 and 25 , starting either from syn-20a or $s y n-20 b$ in $73 \%$ and $65 \%$ yield respectively, and a 82:18 or 83:17 d.r. As the two diastereomers could not be separated the 82:18 mixture of them was characterized. 26,27: colorless oil. $\mathrm{R}_{\mathrm{f}}=0.34$ (PE: $\mathrm{Et}_{2} \mathrm{O}$ 1:1). IR (ATR): $v_{\max } 3417,2976,2936,2908,2876,1734,1681$, 1525, 1456, 1366, 1332, 1288, 1266, 1229, 1209, 1181, 1163, 1101, 1045, 1028, 983, 951, 921, 895, 861, 800, 723. GC-MS: $\mathrm{R}_{\mathrm{t} 1} 9.33 \mathrm{~min}: \mathrm{m} / \mathrm{z} 314\left(\mathrm{M}^{+}-15,21\right), 314(21), 284$ (15), 229 (6.1), 228 (5.5), 184 (9.3), 173 (8.4), 172 (100), 171 (14), 170 (9.3), 155 (16), 154 (11), 152 (10), 143 (6.8), 128 (10), 127 (11), 126 (55), 125 (7.8), 101 (15), 100 (6.0), 99 (11), 98 (22), 97 (11), 88 (12), 87 (22), 85 (26), 84 (13), 83 (6.4), 82 (5.7), 81 (29), 71 (7.2), 70 (5.2), 59 (12), 58 (22), 57 (30), 55 (7.8), 43 (18), 41 (14); $\mathrm{R}_{\mathrm{t} 2} 9.42 \mathrm{~min}: \mathrm{m} / \mathrm{z} 314\left(\mathrm{M}^{+}-15,7.1\right)$, 314 (7.1), 284 (5.2), 242 (5.8), 229 (15), 215 (16), 212 (8.0), 186 (6.6), 184 (14), 173 (5.7), 172 (47), 171 (69), 170 (18), 155 (15), 154 (16), 146 (8.0), 143 (11), 129 (6.1), 128 (8.1), 127 (11), 126 (29), 125 (29), 115 (5.8), 101 (17), 100 (6.1), 99 (11), 98 (16), 97 (31), 89 (6.7), 88 (47), 87 (5.2), 86 (7.2), 85 (100), 84 (28), 83 (8.2), 82 (6.6), 81 (34), 73 (8.2), 72 (6.0), 71 (14), 70 (13), 69 (11), 61 (7.6), 60 (6.3), 59 (31), 58 (41), 57 (63), 56 (8.4), 55 (15), 44 (5.3), 43 (47), 42 (13), 41 (35), 39 (7.7). From NMR spectra of an 82:18 mixture we could extrapolate the spectra of 26 and $27 .{ }^{1} \mathrm{H}-\mathrm{NMR}(\mathbf{2 6})\left(\mathrm{CDCl}_{3}\right): \delta 6.23(\mathrm{~s}, 1 \mathrm{H}, \mathrm{NH}), 4.98(\mathrm{dd}, J=6.0,4.2 \mathrm{~Hz}$, $1 \mathrm{H}, \mathrm{H}-6 \mathrm{a}), 4.72(\mathrm{dd}, J=6.0,3.6 \mathrm{~Hz}, 1 \mathrm{H}, \mathrm{H}-3 \mathrm{a}), 4.25-4.12\left(\mathrm{~m}, 2 \mathrm{H}, \mathrm{CH}_{2} \mathrm{CH}_{3}\right), 4.04(\mathrm{td}, J=6.6,3.6 \mathrm{~Hz}, 1 \mathrm{H}$, $\mathrm{H}-4), 4.01(\mathrm{~d}, J=4.2 \mathrm{~Hz}, 1 \mathrm{H}, \mathrm{H}-6), 2.83,2.78\left(\mathrm{AB}\right.$ part of an $\mathrm{ABX}$ syst., $J_{\mathrm{AB}}=15.2 \mathrm{~Hz}, \mathrm{~J}_{\mathrm{AX}}=5.4 \mathrm{~Hz}$, $\left.J_{\mathrm{BX}}=4.9 \mathrm{~Hz} ., 2 \mathrm{H}, \mathrm{CH}_{2} \mathrm{CO}_{2} \mathrm{Et}\right), 1.43,1.30\left(2 \mathrm{~s}, 2 \times 3 \mathrm{H}, \mathrm{C}\left(\mathrm{CH}_{3}\right)_{2}\right), 1.38\left(\mathrm{~s}, 9 \mathrm{H}, \mathrm{C}\left(\mathrm{CH}_{3}\right)_{3}\right), 1.29(\mathrm{t}, J=7.2 \mathrm{~Hz}$, $\left.3 \mathrm{H}, \mathrm{CH}_{2} \mathrm{CH}_{3}\right) .{ }^{1} \mathrm{H}-\mathrm{NMR}(27)\left(\mathrm{CDCl}_{3}\right): \delta 6.35(\mathrm{~s}, 1 \mathrm{H}, \mathrm{NH}), 5.02(\mathrm{dd}, J=5.4,4.5 \mathrm{~Hz}, 1 \mathrm{H}, \mathrm{H}-6 \mathrm{a}), 4.66-4.59$ $(\mathrm{m}, 2 \mathrm{H}, \mathrm{H}-3 \mathrm{a}, \mathrm{H}-4), 4.28(\mathrm{~d}, J=4.5 \mathrm{~Hz}, 1 \mathrm{H}, \mathrm{H}-6), 4.25-4.12\left(\mathrm{~m}, 2 \mathrm{H}, \mathrm{CH}_{2} \mathrm{CH}_{3}\right), 2.51,2.46$ (AB part of an $\mathrm{ABX}$ syst., $\left.J_{\mathrm{AB}}=14.3 \mathrm{~Hz}, J_{\mathrm{AX}}=5.5 \mathrm{~Hz}, J_{\mathrm{BX}}=6.3 \mathrm{~Hz} ., 2 \mathrm{H}, \mathrm{CH}_{2} \mathrm{CO}_{2} \mathrm{Et}\right), 1.47,1.31(2 \mathrm{~s}, 2 \times 3 \mathrm{H}$, $\left.\left(\mathrm{CCH}_{3}\right)_{2}\right), 1.38\left(\mathrm{~s}, 9 \mathrm{H}, \mathrm{C}\left(\mathrm{CH}_{3}\right)_{3}\right), 1.27\left(\mathrm{t}, J=7.2 \mathrm{~Hz}, 3 \mathrm{H}, \mathrm{CH}_{2} \mathrm{CH}_{3}\right) .{ }^{13} \mathrm{C}-\mathrm{NMR}(27)\left(\mathrm{CDCl}_{3}\right): \delta 170.7,166.3$ $(\mathrm{C}=\mathrm{O}), 112.6$ (C-2), $81.8(\mathrm{C}-6), 81.6(\mathrm{C}-6 \mathrm{a}), 80.3(\mathrm{C}-3 \mathrm{a}), 77.7(\mathrm{C}-4), 60.8\left(\mathrm{CH}_{2} \mathrm{CH}_{3}\right), 51.0\left(\mathrm{C}^{\left.\left(\mathrm{CH}_{3}\right)_{3}\right),}, 33.8\right.$ $\left(\mathrm{CH}_{2} \mathrm{CO}_{2} \mathrm{Et}\right), 28.7\left(\mathrm{C}\left(\mathrm{CH}_{3}\right)_{3}\right), 26.1,25.0\left(\mathrm{CH}_{3} \mathrm{CCH}_{3}\right), 14.2\left(\mathrm{CH}_{3} \mathrm{CH}_{2}\right) .{ }^{13} \mathrm{C}-\mathrm{NMR}(27)\left(\mathrm{CDCl}_{3}\right): \delta 170.0$, $166.6(\mathrm{C}=\mathrm{O}), 112.9(\mathrm{C}-2), 83.9(\mathrm{C}-3 \mathrm{a}), 81.2(\mathrm{C}-6)$, (the peaks of $\mathrm{C}-6 \mathrm{a}$ and $\mathrm{C}-4$ are covered by the signals 


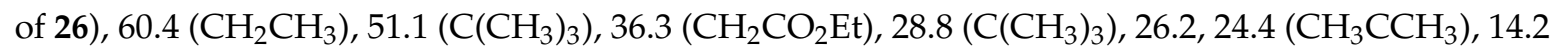
$\left(\mathrm{CH}_{3} \mathrm{CH}_{2}\right)$. HRMS (ESI+): $\mathrm{m} / \mathrm{z} 352.1720\left(\mathrm{M}+\mathrm{Na}^{+}\right) . \mathrm{C}_{16} \mathrm{H}_{27} \mathrm{NNaO}_{6}$ requires: 352.1730 .

(2R,3R,3aS,6aS)-N-(tert-Butyl)-3-hydroxy-5-oxohexahydrofuro[3,2-b]furan-2-carboxamide (31). A solution of $24(25 \mathrm{mg}, 13.2 \mu \mathrm{mol})$ in THF $(759 \mu \mathrm{L})$ and water $(379 \mu \mathrm{L})$ was treated with $\mathrm{CF}_{3} \mathrm{COOH}(379 \mu \mathrm{L})$. The reaction was stirred at r.t. for $48 \mathrm{~h}$ and then refluxed for 6 days. The crude product was evaporated and chromatographed (AcOEt) to afford 31 (17 mg, 92\%) as a white solid. M.p. 153.3-156.1 ${ }^{\circ} \mathrm{C}$ (ACOET). $\mathrm{R}_{\mathrm{f}}=0.31$ (AcOEt). $[\alpha]^{23} \mathrm{D}=-20.88\left(\mathrm{c}=1.08, \mathrm{CHCl}_{3}\right) . \mathrm{IR}(\mathrm{ATR}): v_{\max } 3379,1812,1665,1526,1362,1310$, 1256, 1230, 1199, 1188, 1155, 1141, 1084,1066, 1043 1025, 1005, 939, 908, 861, 845,707, 675, 613. ${ }^{1} \mathrm{H}-\mathrm{NMR}$ $\left(\mathrm{CDCl}_{3}\right): \delta 6.19(\mathrm{~s}, 1 \mathrm{H}, \mathrm{NH}), 5.01(\mathrm{t}, J=4.4,1 \mathrm{H}, H-3 \mathrm{a}), 4.92(\mathrm{ddd}, J=6.0,4.4,1.5 \mathrm{~Hz}, 1 \mathrm{H}, H-6 \mathrm{a}), 4.30$ $(\mathrm{dt}, J=8.1,4.4 \mathrm{~Hz}, 1 \mathrm{H}, H-3), 4.11(\mathrm{~d}, J=8.1 \mathrm{~Hz}, 1 \mathrm{H}, H-2), 3.24(\mathrm{~d}, J=4.8 \mathrm{~Hz}, 1 \mathrm{H}, \mathrm{OH}), 2.82,2.74(\mathrm{AB}$ part of an $\mathrm{ABX}$ syst., $\left.J_{\mathrm{AB}}=18.8 \mathrm{~Hz} ., J_{\mathrm{AX}}=1.5 \mathrm{~Hz}, \mathrm{~J}_{\mathrm{BX}}=6.0 \mathrm{~Hz}, 2 \mathrm{H}, \mathrm{H}-6\right), 1.38\left(\mathrm{~s}, 9 \mathrm{H}, \mathrm{C}\left(\mathrm{CH}_{3}\right)_{3}\right) .{ }^{13} \mathrm{C}-\mathrm{NMR}$ $\left(\mathrm{CDCl}_{3}\right): \delta 174.4,169.2(\mathrm{C}=\mathrm{O}), 82.3(\mathrm{C}-3 \mathrm{a}), 79.3(\mathrm{C}-2), 76.8(\mathrm{C}-6 \mathrm{a}), 75.3(\mathrm{C}-3), 51.4\left(\mathrm{C}^{\left.\left(\mathrm{CH}_{3}\right)_{3}\right),}, 36.6(\mathrm{C}-6)\right.$, $28.7\left(\mathrm{C}\left(\mathrm{CH}_{3}\right)_{3}\right)$. HRMS (ESI+): $m / z 244.1165\left(\mathrm{M}+\mathrm{H}^{+}\right) . \mathrm{C}_{11} \mathrm{H}_{18} \mathrm{NO}_{5}$ requires: 244.1177.

(E)-3-((4R,5S)-5-((tert-butyldimethylsilyl)oxy)methyl)-2,2-dimethyl-1,3-dioxolan-4-yl)prop-2-en-1-ol (35). It was prepared by reduction of $\mathbf{1 8}$, as previously described, to afford a colorless oil in $96 \%$ overall yield [37]. $\mathrm{R}_{\mathrm{f}}=0.36$ ( $\mathrm{PE}: \mathrm{Et}_{2} \mathrm{O} 75: 25$ ). The analytical data agree with the reported ones.

(E)-((4R,5S)-5-((tert-Butyldimethylsilyl)oxy)methyl)-2,2-dimethyl-4-(3-((4-methoxyphenyl)oxy)prop-2-en-1-yl) -1,3-dioxolane (36). A solution of $35(116 \mathrm{mg}, 0.38 \mathrm{mmol})$ in dry $\mathrm{CH}_{2} \mathrm{Cl}_{2}(3.8 \mathrm{~mL})$ was treated with p-methoxyphenol (143 mg, $1.15 \mathrm{mmol})$, and triphenylphosphine (151 mg, $0.58 \mathrm{mmol})$. Then diethyl azodicarboxylate $(97 \%, 93 \mu \mathrm{L}, 0.58 \mathrm{mmol})$ was slowly added at $0{ }^{\circ} \mathrm{C}$. The reaction mixture was then stirred for 4 days at room temperature. The solvent was evaporated under reduced pressure and the residue was purified by column chromatography on silica gel ( $\left.\mathrm{PE}: \mathrm{Et}_{2} \mathrm{O}, 8: 2\right)$ to afford 36 (138 mg, 88\%) as a colorless oil. $\mathrm{R}_{\mathrm{f}}=0.89$ (PE:AcOEt 6:4). $[\alpha]^{34}{ }_{\mathrm{D}}=+2.46\left(\mathrm{c}=0.95, \mathrm{CHCl}_{3}\right)$. IR (ATR): $v_{\max } 2930,2857$, 1507, 1463, 1379, 1228, 1212, 1168, 1096, 1040, 972, 939, 834, 824, 775, 745, 714, 666. GC-MS: Rt 11.58 min: $\mathrm{m} / \mathrm{z} 408\left(\mathrm{M}^{+}, 2.7\right), 293$ (20), 285 (6.0), 227 (5.4), 211 (12), 201 (11), 181 (19), 169 (17), 165 (9.6), 131 (9.3), 125 (16), 124 (37), 123 (37), 117 (8.4), 116 (9.9), 115 (11), 112 (8.0), 111 (100), 109 (8.0), 101 (7.2), 95 (25), 93 (6.0), 89 (29), 83 (5.9), 81 (6.0), 77 (8.8), 75 (39), 74 (8.7), 73 (90), 69 (52), 67 (8.6), 59 (25), 57 (7.8), 55 (8.4), 53 (18), 45 (6.1), 43 (31), 41 (34), 39 (5.8). ${ }^{1} \mathrm{H}-\mathrm{NMR}\left(\mathrm{CDCl}_{3}\right): \delta 6.83(\mathrm{~s}, 4 \mathrm{H}$, aromatic $\mathrm{H}), 5.99(\mathrm{dt}, J=15.6$, $\left.4.8 \mathrm{~Hz}, 1 \mathrm{H}, \mathrm{CH}-\mathrm{CH}_{2} \mathrm{OPMP}\right), 5.91\left(\mathrm{dd}, J=15.6,6.5 \mathrm{~Hz}, 1 \mathrm{H}, \mathrm{CH}=\mathrm{CHCH}_{2} \mathrm{OPMP}\right), 4.69(\mathrm{t}, J=6.5 \mathrm{~Hz}$, $1 \mathrm{H}, H-4), 4.49\left(\mathrm{~d}, J=4.8 \mathrm{~Hz}, 2 \mathrm{H}, \mathrm{CH}_{2} \mathrm{OPMP}\right), 4.20(\mathrm{q}, J=6.1 \mathrm{~Hz}, 1 \mathrm{H}, \mathrm{H}-5), 3.76\left(\mathrm{OCH}_{3}\right), 1.47,1.37$ $\left(2 \mathrm{~s}, 2 \times 3 \mathrm{H},\left(\mathrm{CH}_{3}\right)_{2} \mathrm{C}\right), 0.88\left(\mathrm{~s}, 9 \mathrm{H},\left(\mathrm{CH}_{3}\right)_{3} \mathrm{C}\right), 0.05,0.04\left(2 \mathrm{~s}, 2 \times 3 \mathrm{H}, \mathrm{CH}_{3} \mathrm{Si}\right) .{ }^{13} \mathrm{C}-\mathrm{NMR}\left(\mathrm{CDCl}_{3}\right): \delta$ 153.9, 152.7 (aromatic quat.), 128.9, $128.3(\mathrm{CH}=\mathrm{CH}), 115.6,114.6$ (aromatic $\mathrm{CH}), 108.6(\mathrm{C}-2), 78.5(\mathrm{C}-5)$, $77.7(\mathrm{C}-4), 68.4\left(\mathrm{CH}_{2} \mathrm{OPMP}\right), 62.2\left(\mathrm{CH}_{2} \mathrm{OSi}\right), 55.7\left(\mathrm{OCH}_{3}\right), 27.8,25.4\left(\left(\mathrm{CH}_{3}\right)_{2} \mathrm{C}\right), 25.9\left(\mathrm{C}\left(\mathrm{CH}_{3}\right)_{3}\right), 18.2$ $\left(\mathrm{SiC}\left(\mathrm{CH}_{3}\right)_{2}\right),-5.4\left(\mathrm{Si}\left(\mathrm{CH}_{3}\right)_{2}\right.$. HRMS (ESI+): $m / z 431.2221\left(\mathrm{M}+\mathrm{Na}^{+}\right) . \mathrm{C}_{22} \mathrm{H}_{36} \mathrm{NaO}_{5} \mathrm{Si}$ requires: 431.2230.

((4S,5R)-5-((E)-3-(4-Methoxyphenoxy)prop-1-en-1-yl)-2,2-dimethyl-1,3-dioxolan-4-yl)methanol (37). It was synthesized following the same procedure used for ent-14, starting from 36 (138 mg, $0.34 \mathrm{mmol})$. Chromatography with PE:Et ${ }_{2} \mathrm{O} 3: 7$ afforded 37 as a colorless oil $(98 \mathrm{mg}, 99 \%) . \mathrm{R}_{\mathrm{f}}=0.605\left(\mathrm{PE}_{\mathrm{Et}} \mathrm{E}\right.$ 7:3).

$[\alpha]^{23}{ }_{D}=-33.74\left(\mathrm{c}=0.74, \mathrm{CHCl}_{3}\right)$. IR (ATR): $v_{\max } 3544,3496,2983,2927,2872,1592,1504,1463,1408$, 1385, 1339, 1309, 1292, 1235, 1211, 1184, 1162, 1136, 1109, 1075, 1061, 1028, 1014, 977, 945, 897, 870, 851, 828, 800, 744, 649. GC-MS: R $9.89 \mathrm{~min}: \mathrm{m} / z 294\left(\mathrm{M}^{+}, 2.6\right), 125$ (9.1), 124 (100), 123 (15), 111 (5.3), 109 (14), 95 (5.7), 81 (8.4), 69 (6.6), 59 (21), 57 (5.7), 55 (6.6), 53 (8.8), 44 (7.2), 43 (21), 41 (9.9). ${ }^{1} \mathrm{H}-\mathrm{NMR}$ $\left(\mathrm{CDCl}_{3}\right): \delta 6.83(\mathrm{~s}, 4 \mathrm{H}$, aromatic $\mathrm{H}), 6.04\left(\mathrm{dt}, J=15.6,5.1 \mathrm{~Hz}, 1 \mathrm{H}, \mathrm{CH}-\mathrm{CH}_{2} \mathrm{OPMP}\right), 5.86(\mathrm{dd}, J=15.6,7.2$ $\left.\mathrm{Hz}, 1 \mathrm{H}, \mathrm{CH}=\mathrm{CHCH}_{2} \mathrm{OPMP}\right), 4.70(\mathrm{t}, J=7.0 \mathrm{~Hz}, 1 \mathrm{H}, \mathrm{H}-5), 4.51\left(\mathrm{~d}, J=5.0 \mathrm{~Hz}, 2 \mathrm{H}, \mathrm{CH}_{2} \mathrm{OPMP}\right), 4.26$ $(\mathrm{q}, J=6.0 \mathrm{~Hz}, 1 \mathrm{H}, \mathrm{H}-4), 3.77\left(\mathrm{OCH}_{3}\right), 3.55(\mathrm{t}, J=5.6 \mathrm{~Hz}, 1 \mathrm{H}, \mathrm{OH}), 1.51,1.39\left(2 \mathrm{~s}, 2 \times 3 \mathrm{H},\left(\mathrm{CH}_{3}\right)_{2} \mathrm{C}\right)$. ${ }^{13} \mathrm{C}-\mathrm{NMR}\left(\mathrm{CDCl}_{3}\right): \delta 154.0,152.5$ (aromatic quat.), 130.1, $127.6(\mathrm{CH}=\mathrm{CH}), 115.8,114.6$ (aromatic $\left.\mathrm{CH}\right)$, $108.9(\mathrm{C}-2), 78.3(\mathrm{C}-4), 77.2(\mathrm{C}-5), 68.1\left(\mathrm{CH}_{2} \mathrm{OPMP}\right), 62.0\left(\mathrm{CH}_{2} \mathrm{OH}\right), 55.7\left(\mathrm{OCH}_{3}\right), 27.8,25.2\left(\left(\mathrm{CH}_{3}\right)_{2} \mathrm{C}\right)$. HRMS (ESI+): $m / z 317.2473\left(\mathrm{M}+\mathrm{Na}^{+}\right) . \mathrm{C}_{16} \mathrm{H}_{22} \mathrm{NaO}_{5}$ requires: 317.2462 . 


\section{Conclusions}

In conclusion, we have presented another insight into diastereoselective Passerini reaction were a bio-based chiral aldehyde is involved. Moreover, we exploited the additional functional groups for expanding scaffold diversity, leading to the formation of different oxygenated heterocycles.

Supplementary Materials: The following are available online: Determination of the relative configuration of 16, 20a-i, and 31. Copies of ${ }^{1} \mathrm{H}-\mathrm{NMR}$ and ${ }^{13} \mathrm{C}-\mathrm{NMR}$ spectra. Determination of diasteromeric ratios by ${ }^{1} \mathrm{H}-\mathrm{NMR}$ and HPLC.

Author Contributions: Conceptualization, R.R. and L.M.; Data curation R.R., G.V.F. and C.L.; Formal analysis G.V.F., C.L. and L.M.; Investigation, G.V.F., L.M. and C.L.; Methodology, G.V.F., A.B. and C.L.; Resources, R.R., L.B. and A.B.; Supervision, R.R., L.B. and L.M.; Writing-original draft preparation, R.R. and L.B.; Writing-review and editing, R.R., G.V.F., L.B. and A.B. All authors have read and agreed to the published version of the manuscript.

Funding: This research received no external funding.

Acknowledgments: We thank Christian Tavella for its experimental contribution to this work, Valeria Rocca for HPLC analyses and Andrea Armirotti for HRMS.

Conflicts of Interest: The authors declare no conflict of interest.

\section{References}

1. Bernstein, A.; Sargent, E.H.; Aspuru-Guzik, A.; Cogdell, R.; Fleming, G.R.; Van Grondelle, R.; Molina, M. Renewables need a grand-challenge strategy. Nature 2016, 538, 30. [CrossRef]

2. Isikgor, F.H.; Becer, C.R. Lignocellulosic biomass: A sustainable platform for the production of bio-based chemicals and polymers. Polym. Chem. 2015, 6, 4497-4559. [CrossRef]

3. Cioc, R.C.; Ruijter, E.; Orru, R.V.A. Multicomponent reactions: Advanced tools for sustainable organic synthesis. Green Chem. 2014, 16, 2958-2975. [CrossRef]

4. Banfi, L.; Basso, A.; Moni, L.; Riva, R. The Alternative Route to Enantiopure Multicomponent Reaction Products: Biocatalytic or Organocatalytic Enantioselective Production of Inputs for Multicomponent Reactions. Eur. J. Org. Chem. 2014, 10, 2005-2015. [CrossRef]

5. Cerulli, V.; Banfi, L.; Basso, A.; Rocca, V.; Riva, R. Diversity oriented and chemoenzymatic synthesis of densely functionalized pyrrolidines through a highly diastereoselective Ugi multicomponent reaction. Org. Biomol. Chem. 2012, 10, 1255-1274. [CrossRef]

6. Moni, L.; Banfi, L.; Basso, A.; Bozzano, A.; Spallarossa, M.; Wessjohann, L.; Riva, R. Passerini Reactions on Biocatalytically Derived Chiral Azetidines. Molecules 2016, 21, 1153. [CrossRef]

7. Moni, L.; Banfi, L.; Basso, A.; Galatini, A.; Spallarossa, M.; Riva, R. Enantio- and Diastereoselective Synthesis of Highly Substituted Benzazepines by a Multicomponent Strategy Coupled with Organocatalytic and Enzymatic Procedures. J. Org. Chem. 2014, 79, 339-351. [CrossRef]

8. Moni, L.; Banfi, L.; Basso, A.; Carcone, L.; Rasparini, M.; Riva, R. Ugi and Passerini Reactions of Biocatalytically Derived Chiral Aldehydes: Application to the Synthesis of Bicyclic Pyrrolidines and of Antiviral Agent Telaprevir. J. Org. Chem. 2015, 80, 3411-3428. [CrossRef]

9. Moni, L.; Banfi, L.; Basso, A.; Martino, E.; Riva, R. Diastereoselective Passerini Reaction of Biobased Chiral Aldehydes: Divergent Synthesis of Various Polyfunctionalized Heterocycles. Org. Lett. 2016, 18, 1638-1641. [CrossRef]

10. Moni, L.; Banfi, L.; Cartagenova, D.; Cavalli, A.; Lambruschini, C.; Martino, E.; Orru, R.V.A.; Ruijter, E.; Saya, J.M.; Sgrignani, J.; et al. Zinc(II)-mediated diastereoselective Passerini reactions of biocatalytically desymmetrised renewable inputs. Org. Chem. Front. 2020, 7, 380-398. [CrossRef]

11. Caputo, S.; Basso, A.; Moni, L.; Riva, R.; Rocca, V.; Banfi, L. Diastereoselective Ugi Reaction of Chiral 1,3-Aminoalcohols Derived from an Organocatalytic Mannich Reaction. Beilstein J. Org. Chem. 2016, 12, 139-143. [CrossRef] [PubMed]

12. Caputo, S.; Banfi, L.; Basso, A.; Galatini, A.; Moni, L.; Riva, R.; Lambruschini, C. Diversity-Oriented Synthesis of Various Enantiopure Heterocycles by Coupling Organocatalysis with Multicomponent Reactions. Eur. J. Org. Chem. 2017, 2017, 6619-6628. [CrossRef]

13. Rakicka, M.; Rukowicz, B.; Rywińska, A.; Lazar, Z.; Rymowicz, W. Technology of efficient continuous erythritol production from glycerol. J. Clean. Prod. 2016, 139, 905-913. [CrossRef] 
14. Xiaoyan, L.; Yu, X.; Lv, J.; Xu, J.; Xia, J.; Wu, Z.; Zhang, T.; Deng, Y. A cost-effective process for the coproduction of erythritol and lipase with Yarrowia lipolytica M53 from waste cooking oil. Food Bioprod. Process. 2017, 103, 86-94. [CrossRef]

15. Mach, R.L. Alternative Süßungsmittel. Aktuelle Ernahrungsmed. 2018, 43, 50-54. [CrossRef]

16. Laube, T.; Weisser, J.; Berger, S.; Börner, S.; Bischoff, S.; Schubert, H.; Gajda, M.; Bräuer, R.; Schnabelrauch, M. In situ foamable, degradable polyurethane as biomaterial for soft tissue repair. Mater. Sci. Eng. C 2017, 78, 163-174. [CrossRef] [PubMed]

17. Schmidt, S.; Gatti, F.J.; Luitz, M.; Ritter, B.S.; Bruchmann, B.; Mülhaupt, R. Erythritol Dicarbonate as Intermediate for Solvent- and Isocyanate-Free Tailoring of Bio-Based Polyhydroxyurethane Thermoplastics and Thermoplastic Elastomers. Macromolecules 2017, 50, 2296-2303. [CrossRef]

18. Esmaeili, N.; Jahandideh, A.; Muthukumarappan, K.; Åkesson, D.; Skrifvars, M. Synthesis and characterization of methacrylated star-shaped poly(lactic acid) employing core molecules with different hydroxyl groups. J. Appl. Polym. Sci. 2017, 134, 45341. [CrossRef]

19. Lu, R.; Lu, F.; Si, X.; Jiang, H.; Huang, Q.; Yu, W.; Kong, X.; Xu, J. Production of Plant Phthalate and its Hydrogenated Derivative from Bio-Based Platform Chemicals. ChemSusChem 2018, 11, 1621-1627. [CrossRef]

20. Banfi, L.; Basso, A.; Riva, R. Synthesis of Heterocycles through Classical Ugi and Passerini Reactions Followed by Secondary Transformations Involving One or Two Additional Functional Groups. In Topics in Heterocyclic. Chemistry; Maes, B.U.W., Ed.; Springer: Berlin/Heidelberg, Germany, 2010; Volume 23, pp. 1-39. [CrossRef]

21. Pottie, M.; De Lathauwer, G.; Vandewalle, M. Erythritol: A Versatile Precursor for C-4 Chiral Building Blocks. Bull. Soc. Chim. Belg. 1994, 103, 285-294. [CrossRef]

22. Cohen, N.; Banner, B.L.; Laurenzano, A.J.; Carozza, L. 2,3-O-Isopropylidene-D-erythronolactone [Furo[3,4- $d$ ] -1,3-dioxol-4(3aH)-one, dihydro-2,2-dimethyl-(3aR-cis)-]. Org. Synth. 1985, 63, 127-130.

23. Awasaguchi, K.-I.; Miyazawa, M.; Uoya, I.; Inoue, K.; Nakamura, K.; Yokoyama, H.; Hirai, Y. A Novel Pentose Synthesis via Palladium(II)-Catalyzed Cyclization of an Unstable Hemiacetal. Heterocycles 2010, 81, 2105-2121. [CrossRef]

24. Blanchette, M.A.; Choy, W.; Davis, J.T.; Essenfeld, A.P.; Masamune, S.; Roush, W.R.; Sakai, T. Horner-Wadsworth -Emmons reaction: Use of lithium chloride and an amine for base-sensitive compounds. Tetrahedron Lett. 1984, 25, 2183-2186. [CrossRef]

25. Guanti, G.; Banfi, L.; Narisano, E.; Riva, R.; Thea, S. Enzymes in asymmetric synthesis: Effect of reaction media on the PLE catalysed hydrolysis of diesters. Tetrahedron Lett. 1986, 27, 4639-4642. [CrossRef]

26. Banfi, L.; Guanti, G.; Riva, R. On the optimization of pig pancreatic lipase catalyzed monoacetylation of prochiral diols. Tetrahedron Asymmetry 1995, 6, 1345-1356. [CrossRef]

27. Pilcher, A.S.; Hill, D.K.; Shimshock, S.J.; Waltermire, R.E.; DeShong, P. Selective deprotection of trialkylsilyl ethers using fluorosilicic acid. J. Org. Chem. 1992, 57, 2492-2495. [CrossRef]

28. Trost, B.M.; Caldwell, C.G.; Murayama, E.; Heissler, D. Sulfur-substituted dienes and the silylene protecting group in synthesis. Deoxypillaromycinone J. Org. Chem. 1983, 48, 3252-3265. [CrossRef]

29. Carofiglio, T.; Cozzi, P.G.; Floriani, C.; Chiesi-Villa, A.; Rizzoli, C. Nonorganometallic pathway of the Passerini reaction assisted by titanium tetrachloride. Organometallics 1993, 12, 2726-2736. [CrossRef]

30. Moni, L.; Banfi, L.; Basso, A.; Martino, E.; Riva, R. Correction to “Diastereoselective Passerini Reaction of Biobased Chiral Aldehydes: Divergent Synthesis of Various Polyfunctionalized Heterocycles". Org. Lett. 2016, 18, 3306. [CrossRef]

31. Buchanan, J.G.; Edgar, A.R.; Hewitt, B.D. A new route to chiral hydroxypyrrolidines from D-erythrose via intramolecular 1,3-cycloaddition. J. Chem. Soc. Perkin Trans. 1 1987, 11, 2371-2376. [CrossRef]

32. Shing, T.K.M.; Tsui, H.-C. Goniofufurone: Synthesis and absolute configuration. J. Chem. Soc. Chem. Commun. 1992, 5, 432. [CrossRef]

33. Shing, T.K.M.; Tsui, H.-C. Enantiospecific syntheses of (3S,4R)- and (3S,4R,7S)-diastereoisomers of goniofufurone. Tetrahedron Asymmetry 1994, 5, 1269-1274. [CrossRef]

34. Mereyala, H.B.; Gadikota, R.R.; Joe, M.; Arora, S.K.; Dastidar, S.G.; Agarwal, S. Synthesis and antitumor activity of goniofufurone analogues. Bioorg. Med. Chem. 1999, 7, 2095-2103. [CrossRef]

35. Baba, Y.; Saha, G.; Nakao, S.; Iwata, C.; Tanaka, T.; Ibuka, T.; Ohishi, H.; Takemoto, Y. Asymmetric Total Synthesis of Halicholactone. J. Org. Chem. 2001, 66, 81-88. [CrossRef] [PubMed]

36. Fürstner, A.; Müller, T. The First Synthesis of a 10-Membered Ring by Olefin Metathesis: Jasmine Ketolactone. Synlett 1997, 1997, 1010-1012. [CrossRef] 
37. Kim, G.; Choi, Y.; Sahu, P.K.; Yu, J.; Qu, S.; Lee, D.; Jeong, L.S. Stereoselective Synthesis of d-5-Homo -4-selenoribose as a Versatile Intermediate for 4'-Selenonucleosides. Org. Lett. 2015, 17, 4636-4639. [CrossRef]

38. Banfi, L.; Guanti, G.; Paravidino, M.; Riva, R. Asymmetrized tris(hydroxymethyl)methane as a precursor of $\mathrm{N}$ - and O-containing 6-membered heterocycles through ring-closing metathesis. Org. Biomol. Chem. 2005, 3, 1729-1737. [CrossRef]

39. Nagarapu, L.; Karnakanti, S.; Bantu, R. Total synthesis of sapinofuranone A from d-ribose. Tetrahedron 2012, 68, 5829-5832. [CrossRef]

Sample Availability: No sample of compounds reported in this paper is available from the authors.

(C) 2020 by the authors. Licensee MDPI, Basel, Switzerland. This article is an open access article distributed under the terms and conditions of the Creative Commons Attribution (CC BY) license (http://creativecommons.org/licenses/by/4.0/). 